\title{
Late Ordovician climate change and extinctions driven by elevated volcanic nutrient
} supply

Jack Longman ${ }^{1,2, *}$, Benjamin J. W. Mills ${ }^{3}$, Hayley R. Manners ${ }^{4,5}$, Thomas M. Gernon ${ }^{4}$ and Martin R. Palmer ${ }^{4}$

${ }^{1}$ Marine Isotope Geochemistry, Institute for Chemistry and Biology of the Marine Environment (ICBM), University of Oldenburg, PO Box 2503, 26111 Oldenburg, Germany.

${ }^{2}$ School of Geography and the Environment, University of Oxford, South Parks Road, Oxford, OX1 3QY, UK.

${ }^{3}$ School of Earth and Environment, University of Leeds, Leeds LS2 9JT, UK.

${ }^{4}$ School of Ocean and Earth Sciences, University of Southampton, Southampton, SO14 3ZH, 2 UK.

${ }^{5}$ School of Geography, Earth and Environmental Sciences, University of Plymouth, Plymouth, PL4 8AA, UK.

\section{${ }^{*}$ Corresponding Author: jack.longman@uni-oldenburg.de}

\begin{abstract}
The Late Ordovician ( 459-444 million years ago) was characterised by global cooling, glaciation and severe mass extinction. These events may have been driven by increased delivery of the nutrient phosphorus $(P)$ to the ocean, and associated increases in marine productivity, but it is not clear why this occurred in the two pulses identified in the geological record. We link both cooling phases, and the extinction, to volcanic eruptions through marine deposition of nutrient-rich ash and the weathering of terrestrially emplaced ash and lava. We then reconstruct the influence of Late Ordovician volcanic $\mathbf{P}$ delivery on the marine system by coupling an estimate of bioavailable phosphate supply
\end{abstract}


(derived from a depletion and weathering model) to a global biogeochemical model. Our model compares volcanic ash $P$ content in marine sediments before and after alteration to determine depletion factors, and we find good agreement with observed carbon isotope and reconstructed temperature shifts. Hence, massive volcanism can drive substantial global cooling on million-year timescales due to $\mathbf{P}$ delivery associated with long-term weathering of volcanic deposits, offsetting the transient warming of greenhouse gas emission associated with volcanic eruptions. Such longer-term cooling and potential for marine eutrophication may be important for other volcanism-driven global events.

\section{Main Text}

The Late Ordovician mass extinction (LOME) occurred in two phases, and in terms of species loss was the second greatest extinction event in Earth's history ${ }^{1-3}$. The Late Ordovician is characterised by a number of carbon isotope excursions (CIEs), with two globallyrepresented, the Guttenburg (GICE) at $\sim 454 \mathrm{Ma}$, and Hirnantian (HICE) at $\sim 445 \mathrm{Ma}^{4}$. The GICE coincides with global cooling, and the beginning of the HICE is associated with widespread glaciation, with the cooling periods generally implicated in instigating the $\mathrm{LOME}^{1,5-7}$

The primary driver behind the CIEs and associated cooling is uncertain. One possibility is that the emergence of early nonvascular land plants amplified terrestrial weathering and increased the delivery of the key limiting nutrient phosphorus to the oceans ${ }^{8}$. Greater availability of phosphorus increases marine productivity and organic carbon burial, driving a reduction in atmospheric $\mathrm{CO}_{2}$ and a positive excursion in carbonate $\delta^{13} \mathrm{C}$ (ref. ${ }^{9}$ ). Other proposals include an increasing fraction of eukaryotic marine production strengthening the biological pump ${ }^{10}$, and increased tropical weathering resulting from orogenesis augmenting the supply of phosphorus to the oceans ${ }^{11}$. 
The concept that Late Ordovician cooling was driven by organic carbon burial is supported by observations ${ }^{12}$, but why this occurred in two distinct pulses during the GICE and HICE is unclear. This pulsing may have arisen from early plants colonising new terranes ${ }^{8}$, but there is little evidence for this, although poor fossil preservation cannot be ruled out ${ }^{13}$.

Further, the pace of early plant evolution remains highly uncertain ${ }^{13}$ and there is no evidence that eukaryotic evolution, or tropical uplift, occurred in distinct pulses. Existing global biogeochemical models cannot reliably reproduce the Hirnantian glaciation (or isotope excursions) associated with the HICE when based on known long-term tectonic cycles of uplift and degassing, and the positioning of the continents ${ }^{9}$, even though these models can accurately reproduce the Permo-Carboniferous and late Cenozoic icehouses ${ }^{9}$. This suggests that the Hirnantian icehouse was driven by some climatic forcing mechanism currently not well-represented in these models.

Given the potential association between volcanism and global climate change ${ }^{14,15}$, we explore the concept that Late Ordovician marine productivity and cooling episodes were directly related to subaerial volcanic activity. The Late Ordovician was characterised by extensive volcanic eruptions, preserved in the sedimentary record as bentonites ${ }^{16,17}$. These bentonites represent some of the largest volcanic eruptions in Earth's history, with estimates indicating some of the better studied events (Millbrig, Deicke and Kinnekulle) erupted $\geq 1000$ $\mathrm{km}^{3}$ of pyroclastic material ${ }^{18}$. In addition, there are hundreds of spatially extensive bentonites of Late Ordovician $(459-444 \mathrm{Ma})$ age preserved across North America ${ }^{19}$, Northern Europe ${ }^{20}$, and China ${ }^{16,21}$, prompting suggestions of a causal link between volcanism and global cooling during this period ${ }^{3,14,17}$. Most recently, several studies have employed the total organic carbon to mercury ratio $(\mathrm{TOC} / \mathrm{Hg})$, to directly link volcanic $\mathrm{Hg}$ emission to Late Ordovician climatic change (e.g. refs. ${ }^{22,23}$ ). However, it remains uncertain whether cooling was driven by rapid sulfate emissions, through the immediate weathering of ash and lava, or by longer-term 
weathering of volcanic arcs and uplifted terranes ${ }^{17,23}$, a problem compounded by poorly constrained volcanic fluxes.

Volcanism may cool the climate on non-transitory timescales due to enhanced productivity and organic carbon preservation ${ }^{24}$, with one of the key drivers being enhanced $\mathrm{P}$ supply derived from leaching of volcanic ash ${ }^{25}$. It is not currently clear how much P may have been supplied from ash during the Late Ordovician, or how input of volcanic P may have influenced the marine environment. To answer these questions, we compile global data on $\mathrm{P}$ depletion in tephra layers today, as a method of quantifying P release to the ocean during ash deposition and diagenesis. We couple our estimates of $\mathrm{P}$ flux to a global biogeochemical model to investigate the potential impact of such nutrient supply to the Late Ordovician marine carbon cycle.

\section{Timing and extent of volcanism during the Late Ordovician}

To estimate timing of volcanic activity, we compile $43 \mathrm{Ar}-\mathrm{Ar}$ and $\mathrm{U}-\mathrm{Pb}$ dates from North American and Scandinavian bentonites (Fig. 1a), and 24 dates from Chinese bentonites of Late Ordovician age (Fig. 1b). Our reconstruction indicates that bentonite deposition occurred in two discrete pulses (Fig. 1c), corresponding to the eruption of two geographically distinct volcanic provinces (Figure 2). The first pulse represents North American/Scandinavian volcanism and is well-constrained, with the greatest depositional intensity occurring between 454.5 - 453 Ma, peaking at 453.5 Ma (Fig. 1c). This peak primarily represents highly-precise measurements of the North American "big" bentonites, the Deicke and Millbrig, 5,26 , and the Grimstorp bentonite ${ }^{26}$. A slightly earlier peak is also apparent (c. $456.5 \mathrm{Ma}$ ), representing potentially uncertain estimates of the Kinnekulle bentonite $\operatorname{age}^{27}$, and other unnamed bentonites from Oslo $^{20}$ (see Supplementary Table 4). Chinese bentonite ages exhibit more spread, with fewer highly precise dates (Fig. 1c). Our compilation suggests the most intense volcanism in the China region occurred between 445.25 
- 442.5 Ma, with a peak at about $444 \mathrm{Ma}$ (Fig. 1c), corresponding to some of the most accurate dates from outcrop in the south-western Yunnan province ${ }^{28}$, and central Hubei province $^{29}$. These two volcanic pulses correspond well to the two primary carbon isotope excursions of the Late Ordovician, the GICE and HICE, and may thus support a link between volcanism and climate change.

\section{$P$ release during ash deposition, diagenesis and weathering}

To investigate this hypothesis, we estimate the amount of $\mathrm{P}$ which may have been supplied by the two main pulses of volcanism. To estimate the percentage of $\mathrm{P}$ released during ash deposition and diagenesis, altered ash compositions are compared to unaltered protolith compositions to estimate metal mobility ${ }^{30,31}$, using protolith data from the GEOROC database (http://georoc.mpch-mainz.gwdg.de) and our data from altered tephras (see Methods). Specifically, marine sediment-hosted tephras from the Lesser Antilles and the Aleutian arcs have been analysed and compared to similar data from eight additional modern volcanic provinces (Fig. 1). In addition to direct input of P from volcanic ash deposition, the emplacement and subsequent terrestrial weathering of extensive ash beds would have led to a secondary source of $\mathrm{P}$ to the oceans. The scale of this $\mathrm{P}$ flux has been estimated from a Monte Carlo simulation of inputs using published variables including the number, and scale of eruptions (Methods, Extended Data Figures 1, 2).

Depletion factors indicate between $31 \%$ (mean) and $48 \%$ (median) of the P originally hosted in tephra is lost during early diagenesis (Fig. 3). The potential scale of this process is calculated in the modern oceans, using an average of $1.14 \pm 0.6 \mathrm{~km}^{3}$ ash deposited per year, with $70 \pm 7.5 \%$ falling into the ocean ${ }^{31}$, an ash density of $1400 \pm 130 \mathrm{~kg} / \mathrm{m}^{3}\left(\right.$ ref. $^{32}$ ), and an original P content in tephra of $0.41 \pm 0.19 \mathrm{wt} \%\left(\right.$ ref. $\left.^{33}\right)$. For each variable, a Monte Carlobased approach is applied, using the average and standard deviation to develop 10,000 possible iterations of each variable. From this calculation, the most likely annual $\mathrm{P}$ flux from 


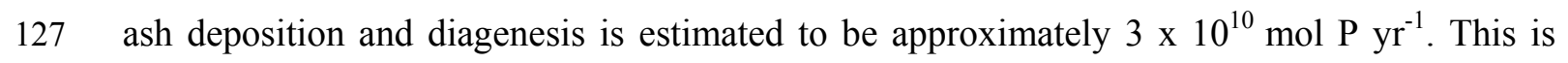

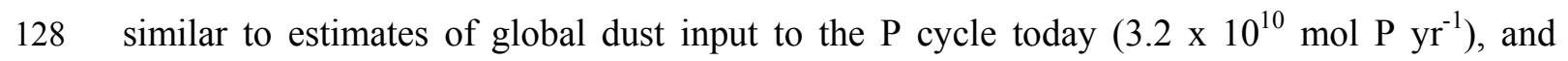
129 exceeds the dissolved riverine input $\left(0.6-1.1 \times 10^{10} \mathrm{~mol} \mathrm{P} \mathrm{yr}^{-1} ;\right.$ ref. $\left.^{34}\right)$. Present-day volcanism

130 is thought to be far smaller in scale than in periods such as the Ordovician ${ }^{35,36}$. Therefore, 131 enhanced $\mathrm{P}$ supply tied to volcanism likely played an even more important role in 132 biogeochemical cycles of $\mathrm{P}$ during the Ordovician.

\section{Impact of volcanic ash supply on Late Ordovician climate}

134 The depletion factors and estimates of ash supply during the Late Ordovician can be used to quantify the scale of $\mathrm{P}$ supply during the two studied events. For the GICE, our simulations indicate a mean of $2.29 \times 10^{15}$ mol P (Fig. 4), which increases to $6.49 \times 10^{15} \mathrm{~mol}$ $\mathrm{P}$ in the upper estimates of the simulations $\left(95^{\text {th }}\right.$ percentile). For the volcanic episode covering of $8.24 \times 10^{15} \mathrm{~mol} \mathrm{P}\left(95^{\text {th }}\right.$ percentile) (Fig. 4). In addition to ash falling into the ocean, the impact of erosion of terrestrially emplaced ash and lava on the $\mathrm{P}$ cycle is considered by estimating weathering fluxes of $\mathrm{P}$ (Methods). Newly emplaced ashes and basaltic rocks weather rapidly ${ }^{37,38}$, such that in Earth's modern configuration, despite representing only 3 $5 \%$ of land area, chemical weathering of basalt contributes $\sim 30 \%$ of the total $\mathrm{CO}_{2}$ consumption by silicate weathering ${ }^{37,38}$. Our approach to quantifying the impact of this process results in a mean additional (riverine) $\mathrm{P}$ flux from weathering of $7.51 \times 10^{14} \mathrm{~mol} \mathrm{P}$ $\mathrm{Myr}^{-1}$ in the millennia after emplacement (Fig. 4c), with an upper estimate of $1.23 \times 10^{15} \mathrm{~mol}$ $\mathrm{P} \mathrm{Myr}^{-1}$ (95 ${ }^{\text {th }}$ percentile), providing another source of bioavailable $\mathrm{P}$ to the ocean system.

The impact of this level of volcanic nutrient supply on Ordovician climate is estimated using the COPSE global biogeochemical model ${ }^{39}$. The GICE and HICE P inputs are represented by Gaussian functions with their maxima at the times of highest depositional intensity noted above (i.e., 453.5 and $444 \mathrm{Ma}$ ) and with a width of 2 Myrs, constrained in part 
152 by the duration of the carbon isotope excursions. The total $\mathrm{P}$ input is calculated for both the 153 means and $95^{\text {th }}$ percentiles and is summed from the $\mathrm{P}$ depletion model and weathering inputs. 154 A further factor is also added into the $\mathrm{P}$ delivery calculation to represent the recycling of $\mathrm{P}$ 155 from sediments, because $\mathrm{P}$ loading and eutrophication in marginal settings leads to a 156 substantial recycling flux of $\mathrm{P}$ from the sediments ${ }^{40}$, due to the increase in anaerobic 157 processing of organic matter and the scarcity of Fe(III) phases that scavenge P. The COPSE 158 model does not represent these feedbacks well, because it has a well-mixed global ocean and 159 no consideration of continental margins, with substantial recycling of $\mathrm{P}$ relying on 160 eutrophication of the global ocean rather than productive shelves and slope environments 161 alone ${ }^{39}$. This is relevant to the Ordovician, a time when sea level was perhaps $300 \mathrm{~m}$ higher 162 than present ${ }^{41}$, with extensive shelf environments ${ }^{42}$. Hence, parallel experiments were run to 163 determine the degree to which P recycling is dampened in COPSE versus a published P cycle 164 model in which the shelves are considered separately (see Methods, ref. $^{43}$ ). We conclude that 165 a 5-fold larger $\mathrm{P}$ input is required in COPSE to produce the same spike in marine $\mathrm{P}$ 166 concentration observed in the multi-box model (Extended Data Figure 3). Thus, P inputs in 167 the additional COPSE simulations are increased 5-fold to represent both the initial input and 168 the additional recycling of $\mathrm{P}$. The large size of this factor is related to the relatively small size 169 of the ocean shelves (as a fraction of the whole ocean) compared to their disproportionately 170 large contribution to organic matter burial.

171 An important parameter in COPSE is the degree to which land plants amplify continental weathering rates. This value is poorly constrained and is typically varied in sensitivity analyses between around 2- and 7-fold, giving a wide range of possible background $\mathrm{CO}_{2}$ concentrations for the early Palaeozoic ${ }^{44}$. We choose a factor 2 enhancement for the model runs in this work, which gives a relatively low background Ordovician $\mathrm{CO}_{2}$ concentration of around $1000 \mathrm{ppm}$, consistent with more recent proxy data ${ }^{45}$. Other than the 177 new $\mathrm{P}$ inputs and choice of biotic weathering parameter, the model remains identical to the 
178 long-term baseline shown in ref. ${ }^{39}$. Figure 5 shows the model outputs for atmospheric $\mathrm{CO}_{2}$, 179 average surface temperature, marine anoxia, and the $\delta^{13} \mathrm{C}$ of new sedimentary carbonates. The 180 model outputs show that the P release from volcanic ash deposition and weathering, combined 181 with the recycling of $\mathrm{P}$ from sediments, is sufficient to cause large-scale changes in climate 182 and biogeochemistry as observed in the geological record ${ }^{10,14}$. In the " $95^{\text {th }}$ percentile + 183 recycling" input scenario, carbon isotope excursions of $\sim 3 \%$ and $\sim 4 \%$ are predicted, which 184 are synchronous with the GICE and HICE, respectively, and are of similar magnitude. In this 185 scenario, maximum global cooling at the $\mathrm{HICE}$ is around $3^{\circ} \mathrm{C}$, and a global average surface temperature of below $15^{\circ} \mathrm{C}$ is reached at the nadir. These temperature predictions are in line with clumped isotope thermometry which suggests the Hirnantian icehouse was relatively short lived and represented a similar global average temperature to recent Pleistocene glaciation $^{6,46}$.

The extent of marine anoxia increases during the $\mathrm{P}$ input events in the model, although given the global well-mixed ocean in the model, shelf anoxia would be expected to increase by a larger fraction than the global ocean. This is against a backdrop of marine oxygenation through the Ordovician and Silurian predicted by $\mathrm{COPSE}^{39}$. One of the major features of the HICE in the geological record is the widespread formation of organic-rich shales, in particular in China ${ }^{47,48}$, potentially linked to widespread ocean anoxia ${ }^{10,49}$. In COPSE, the relative increase in anoxia is much larger during the HICE - close to a doubling in the " $95^{\text {th }}$ percentile + recycling" scenario.

\section{Implications for the LOME}

Our model results suggest that volcanic ash diagenesis and weathering of erupted products likely played a key role in the Late Ordovician Earth system. In order to reproduce the magnitude of Earth system change, we require that these inputs are at the $95^{\text {th }}$ percentile of our analysis. However, given the relatively sparse nature of the geological record of the 
Palaeozoic, and the conservative approach utilised here to derive estimates of $\mathrm{P}$ supply from

204 ash (Methods), we stress that our analysis likely underestimates the number of volcanic

205 events. This is supported by the close comparison between the model output of the "95th

206 percentile + recycling" input scenario and proxy data (Fig. 5, ref. ${ }^{50}$ ). Our results may explain

207 several features of the LOME, which do not follow trends associated with other mass

208 extinctions, in particular their link to cooling, rather than warming. Volcanic activity has been

209 invoked as the driver behind a number of short-term climatic upheavals and mass

210 extinctions $^{51}$, including those at the end of the Permian ${ }^{52}$ and in the Triassic periods ${ }^{53}$,

211 resulting in the rapid fluctuations between icehouse and greenhouse conditions known to

212 stress faunas and drive biodiversity $\operatorname{loss}^{3,52}$.

For the Late Ordovician, it appears that the long-term nature of nutrient supply from weathering of eruptive products such as volcanic ash plays a more dominant role than the medium-term warming associated with $\mathrm{CO}_{2}$ injection. When comparing to climatic change, it is clear that the first stepped decrease in faunal diversity occurred soon after the GICE, with two further decreases occurring temporally close to the $\mathrm{HICE}^{3,54}$. Our approach considers many eruptions to estimate nutrient supply on a coarse scale. The super-eruptions represented by bentonites would likely have led to initial cooling (due to injection of stratospheric aerosols), followed by warming (from $\mathrm{CO}_{2}$ injection), before cooling because of increases in nutrient supply and associated productivity levels. The warming/cooling cycles this scenario represents are purportedly dangerous for organisms, with biodiversity loss occurring when temperatures fall outside the optimal window ${ }^{3}$, potentially explaining the LOME initiation. Due to their global nature, we focus on the HICE and GICE, and only model two P pulses. However, bentonite ages suggest that multiple eruptions occurred between the two largest volcanic episodes and CIEs (Fig. 1), which may have led to transient local CIEs, such as those reported in the Scandinavian sections ${ }^{7}$. 
In addition to releasing nutrients, it is possible that other toxic metals are also released

229 during ash alteration and diagenesis ${ }^{25}$. During the Hirnantian glaciation and the HICE, there is

230 evidence for metal-induced malformations in fossil plankton assemblages ${ }^{55}$. Further, volcanic

231 ash may lead to the formation of large-scale anoxic conditions below deposited blankets ${ }^{24}$,

232 which may have further enhanced redox-based recycling of toxic metals ${ }^{55}$ and led to the

233 deposition of widespread black shales ${ }^{47}$. Using the evidence presented here, we conclude that

234 the pulsed nature of global cooling at this time appears to be a result of the eruption of two

235 distinct volcanic provinces, one in what is now North America and the Baltic, and one in what

236 is now Southern China. Further, our models suggest that the deposition of extensive ash

237 blankets and weathering of lavas emplaced during Late Ordovician volcanism, supplied

238 sufficient $\mathrm{P}$ to drive global cooling, glaciation, and the LOME.

\section{Acknowledgements}

240 This work was funded by NERC grant NE/K00543X/1, "The role of marine diagenesis of 241 tephra in the carbon cycle". B.J.W.M. acknowledges support from NERC grant 242 NE/S009663/1. T.M.G. acknowledges support of NERC grant NE/R004978/1, and funding 243 from the Alan

244 Turing Institute (EP/N510129/1). We are grateful for comments from Christian Rasmussen 245 and the anonymous reviewer(s), which helped to improve the manuscript. We are grateful to 246 staff of the IODP Gulf Coast Repository and IODP Kochi Core Repository for their assistance 247 during sampling of cores U1396C and U1339D, respectively.

\section{Author Contributions}

249 J.L., T.M.G. and M.R.P. conceived this research. J.L. and H.R.M. completed the laboratory 250 analyses. B.J.W.M. completing the modelling and J.L. compiled and analysed the data. J.L. 
and B.J.W.M. created the figures. J.L. and B.J.W.M. wrote the manuscript, with input from

252 T.M.G., H.R.M. and M.R.P.

\section{Competing Interests}

254 The authors declare no competing interests.

\section{Corresponding Author}

All correspondence and request for materials should be addressed to Jack Longman (jack.longman@uni-oldenburg.de)

\section{Figure Captions}

Figure 1: Compilation of Late Ordovician bentonite ages from North America and

China. Bentonites ages in North America/Scandinavia (a), and China (b). Each age is represented by a probability density curve derived from published mean and standard deviation, from which 10,000 Monte Carlo simulations were completed and binned at 0.25 Myr intervals to attain probability densities of the eruption occurring in each bin. Colours correspond to the studies from which each age is obtained. c, Average probability densities for each 0.25 Myr bin, for the North American (blue) and Chinese bentonites (red). Vertical lines indicate the bin in which bentonite deposition is most likely. (See Supplementary Tables

2674 and 5 for references).

Figure 2: Paleogeographic reconstruction for the Late Ordovician at c. 450 Ma (Katian).

Marked with ellipses are the two volcanic provinces investigated in this study, with blue ellipses representing the North American and Scandinavian province, and a green ellipse to represent the Chinese province. The base map was constructed using the plate tectonic

272 reconstructions from ref. ${ }^{56}$ and is based partly on $\operatorname{ref}^{57}$.Figure 3: Box and whisker diagrams 273 of phosphorus depletion, an indicator of the amount of phosphorus lost to the ocean, 
275 first and third quartile (the interquartile range, IQR), with minimum and maximum whiskers

276 representative of 1.5 times the IQR. Also shown is a map of each volcanic province used for

277 this reconstruction (b), with the provinces identified by numbers given in panel (a).Figure 4:

278 Monte Carlo simulations of phosphorus supply from volcanic weathering during the

279 Late Ordovician, with variable distributions defined by our ash depletion and

280 weathering model. (a) and (b) represent P supply from ash deposition and diagenesis. In both

281 panels, the total ash volume is presented along the $\mathrm{x}$-axis, with total phosphorus supply on the

282 y-axis. Each Monte Carlo simulation is indicated by a circle, with the colour indicating the

283 depletion factor. (c) Estimate of P flux resulting from weathering of terrestrial volcanic matter

284 (y-axis), plotted against the area covered by this ash and lava. Again, each simulation is

285 indicated by a filled circle, with the colour denoting the rate of phosphorus supply.

Figure 5. Biogeochemical model outputs for impacts of volcanism during the GICE and HICE. COPSE model baseline runs ${ }^{39}$ plus $\mathrm{P}$ supply from ash. a, Grey lines show the P input Gaussian functions (see text). The P input magnitude follows the mean or $95^{\text {th }}$ percentiles of the values derived for ash supply and weathering combined, with or without recycling of $\mathrm{P}$ from sediments (see main text). b, Modelled $\delta^{13} \mathrm{C}$ of carbonates (with colours defined in panel e) compared to data ${ }^{50}$ (yellow circles). c, Modelled atmospheric $\mathrm{CO}_{2}$. d, Modelled global average surface temperature. e, Degree of marine anoxia (represented as the modelled proportion of anoxic seafloor). Solid lines show the same simulations as the dashed lines, but with additional $\mathrm{P}$ input to represent sedimentary recycling of $\mathrm{P}$ (see text).

\section{References}

1. Harper, D. A. T., Hammarlund, E. U. \& Rasmussen, C. M. Ø. End Ordovician extinctions: A coincidence of causes. Gondwana Res. 25, 1294-1307 (2014).

2. Bambach, R. K., Knoll, A. H. \& Wang, S. C. Origination, extinction, and mass depletions of marine diversity. Paleobiology 30, 522-542 (2004). 
301 Paleozoic marine radiations paused by Late Ordovician extinctions. Proc. Natl. Acad. Sci. U. S. A. $302116,7207-7213(2019)$.

303 4. Bergström, S. M., Schmitz, B., Saltzman, M. R. \& Huff, W. D. The Upper Ordovician 304 Guttenberg $813 \mathrm{C}$ excursion (GICE) in North America and Baltoscandia: Occurrence, 305 chronostratigraphic significance, and paleoenvironmental relationships. Geol. Soc. Am. Spec. Pap. $306466,37-67(2010)$.

307 5. Metzger, J. G., Ramezani, J., Bowring, S. A. \& Fike, D. A. New age constraints on the 308 duration and origin of the Late Ordovician Guttenberg $\delta^{13} \mathrm{C}_{\text {carb }}$ excursion from high-precision U-Pb 309 geochronology of K-bentonites. GSA Bull. (2020) doi:10.1130/B35688.1.

310 6. Finnegan, S. et al. The magnitude and duration of late Ordovician-early Silurian glaciation. 311 Science. 331, 903-906 (2011).

312 7. Ainsaar, L. et al. Middle and Upper Ordovician carbon isotope chemostratigraphy in 313 Baltoscandia: A correlation standard and clues to environmental history. Palaeogeogr. Palaeoclimatol. 314 Palaeoecol. 294, 189-201 (2010).

315 8. Lenton, T. M., Crouch, M., Johnson, M., Pires, N. \& Dolan, L. First plants cooled the 316 Ordovician. Nat. Geosci. 5, 86-89 (2012).

317 9. Mills, B. J. W. et al. Modelling the long-term carbon cycle, atmospheric CO2, and Earth 318 surface temperature from late Neoproterozoic to present day. Gondwana Research vol. 67 172-186 319 (2019).

320 10. Shen, J. et al. Improved efficiency of the biological pump as a trigger for the Late Ordovician 321 glaciation. Nat. Geosci. 11, 510-514 (2018).

322 11. Swanson-Hysell, N. L. \& Macdonald, F. A. Tropical weathering of the Taconic orogeny as a 323 driver for Ordovician cooling. Geology 45, 719-722 (2017). 
324 12. Bartlett, R. et al. Abrupt global-ocean anoxia during the Late Ordovician-early Silurian 325 detected using uranium isotopes of marine carbonates. Proc. Natl. Acad. Sci. U. S. A. 115, 5896-5901 326 (2018).

327 13. Morris, J. L. et al. The timescale of early land plant evolution. Proc. Natl. Acad. Sci. U. S. A. 328 115, E2274-E2283 (2018).

329 14. Buggisch, W. et al. Did intense volcanism trigger the first Late Ordovician icehouse? Geology $330 \quad 38,327-330(2010)$.

331 15. Herrmann, A. D., Leslie, S. A. \& MacLeod, K. G. Did intense volcanism trigger the first Late 332 Ordovician icehouse?: COMMENT. Geology 39, e237-e237 (2011).

333 16. Huff, W. D., Bergström, S. M. \& Kolata, D. R. Ordovician explosive volcanism. Geol. Soc. 334 Am. Spec. Pap. 466, 13-28 (2010). 17. Tao, H., Qiu, Z., Lu, B., Liu, Y. \& Qiu, J. Volcanic activities triggered the first global cooling event in the Phanerozoic. J. Asian Earth Sci. 104074 (2019) doi:10.1016/j.jseaes.2019.104074. Ordovician volcanic ash falls in North America and Europe: Dimensions, emplacement and postemplacement characteristics. J. Volcanol. Geotherm. Res. 73, 285-301 (1996). (Sandbian-Katian) K-bentonites of eastern North America. Bull. Geol. Soc. Am. 127, 1259-1274 342 (2015). Ordovician (Sandbian) K-bentonites in Oslo, Norway. Palaeogeogr. Palaeoclimatol. Palaeoecol. 520, 203-213 (2019). doi:10.1144/jgs2020-049. 
350 Volcanic Trigger for the Late Ordovician Mass Extinction Event: An Example from a Deep Shelf of 351 the Peri-Baltic Region. Sci. Rep. 9, 1-11 (2019).

352 23. Jones, D. S., Martini, A. M., Fike, D. A. \& Kaiho, K. A volcanic trigger for the late 353 Ordovician mass extinction? Mercury data from south China and Laurentia. Geology 45, 631-634 354 (2017).

355 24. Longman, J., Palmer, M. R., Gernon, T. M. \& Manners, H. R. The role of tephra in enhancing 356 organic carbon preservation in marine sediments. Earth-Science Rev. 192, 480-490 (2019).

357 25. Jones, M. T. \& Gislason, S. R. Rapid releases of metal salts and nutrients following the 358 deposition of volcanic ash into aqueous environments. Geochim. Cosmochim. Acta 72, 3661-3680 359 (2008).

360 26. Sell, B., Ainsaar, L. \& Leslie, S. Precise timing of the Late Ordovician (Sandbian) super361 eruptions and associated environmental, biological, and climatological events. J. Geol. Soc. London. $362170,711-714(2013)$.

363 27. Tucker, R. D. \& McKerrow, W. S. Early Paleozoic chronology: a review in light of new U-Pb 364 zircon ages from Newfoundland and Britain. Can. J. Earth Sci. 32, 368-379 (1995).

365 28. Ling, M. X. et al. An extremely brief end Ordovician mass extinction linked to abrupt onset of 366 glaciation. Solid Earth Sci. 4, 190-198 (2019).

367 29. Du, X. et al. Was volcanic activity during the Ordovician-Silurian transition in South China 368 part of a global phenomenon? Constraints from zircon $\mathrm{U}-\mathrm{Pb}$ dating of volcanic ash beds in black 369 shales. Mar. Pet. Geol. 114, 104209 (2020).

370 30. Lee, C.-T. A. et al. Volcanic ash as a driver of enhanced organic carbon burial in the 371 Cretaceous. Sci. Rep. 8, 4197 (2018).

372 31. Longman, J., Palmer, M. R., Gernon, T. M. \& Manners, H. R. Subaerial volcanism is a major 373 contributor to oceanic iron and manganese cycles. In Review. 

of Eyjafjallajökull, Iceland. Sci. Rep. 2, 572 (2012). dynamics during the Eyjafjallajökull 2010 eruption. Am. Mineral. 102, 1173-1186 (2017). (2007). Ma: A global compilation. Earth Planet. Sci. Lett. 461, 85-95 (2017). degassing rates prevented the return of Snowball Earth during the Phanerozoic. Nat. Commun. 8, 1-7 (2017). and the impact of basalt weathering on the global carbon cycle. Chem. Geol. 202, 257-273 (2003). global climate and the 87Sr/86Sr ratio of seawater. Earth Planet. Sci. Lett. 188, 459-474 (2001). during the Neoproterozoic and Palaeozoic. Interface Focus 10, 20190137 (2020). circulation. Biogeosciences 4, 155-171 (2007). accumulation in shallow-shelf and deep-marine settings. J. Geol. 110, 75-87 (2002). 

(1991).

45. Witkowski, C. R., Weijers, J. W. H., Blais, B., Schouten, S. \& Sinninghe Damsté, J. S. Molecular fossils from phytoplankton reveal secular PCO2 trend over the phanerozoic. Sci. Adv. 4, eaat4556 (2018).

46. Goldberg, S. L., Present, T. M., Finnegan, S. \& Bergmann, K. D. A high-resolution record of early Paleozoic climate. Proc. Natl. Acad. Sci. 118, (2021).

47. Zou, C. et al. Organic-matter-rich shales of China. Earth-Science Reviews vol. 189 51-78 (2019).

48. Su, W. et al. K-bentonite, black-shale and flysch successions at the Ordovician-Silurian transition, South China: Possible sedimentary responses to the accretion of Cathaysia to the Yangtze Block and its implications for the evolution of Gondwana. Gondwana Res. 15, 111-130 (2009). Hirnantian glaciation. Palaeogeogr. Palaeoclimatol. Palaeoecol. 276, 182-195 (2009). (eds. Gradstein, F. M., Ogg, J.., Schmitz, M. D. \& Ogg, G, M.) 207-232 (Elsevier, 2012). doi:10.1016/B978-0-444-59425-9.00011-1.

51. Sobolev, S. V. et al. Linking mantle plumes, large igneous provinces and environmental catastrophes. Nature 477, 312-316 (2011). sulfur outgassing. Nat. Geosci. 11, 949-954 (2018). Triassic mass extinction and flood basalt volcanism at the 100 ka level. Geology 38, 387-390 (2010). biodiversity. Science . 367, 272-277 (2020). 
55. Vandenbroucke, T. R. A. et al. Metal-induced malformations in early Palaeozoic plankton are harbingers of mass extinction. Nat. Commun. 6, (2015).

56. Merdith, A. S. et al. Extending full-plate tectonic models into deep time: Linking the Neoproterozoic and the Phanerozoic. Earth-Science Rev. 214, 103477 (2021). Gondwana Res. (2020) doi:10.1016/j.gr.2020.09.008.

\section{Methods}

\section{Major and trace element geochemistry}

were analysed for their phosphorus content. Tephras were identified visually, and microscopically, in core 1339D and through their low $\mathrm{CaCO}_{3}$ content in U1396C. P was analysed in tephra layers after mixed acid $\left(\mathrm{HNO}_{3}-\mathrm{HCl}-\mathrm{HF}\right)$ bench-top digestion. Samples were then analysed on a Perkin Elmer 2000B at the University of Oxford. Analysis was completed in both standard mode $(\mathrm{m} / \mathrm{z} 31)$ and in reaction mode, with $\mathrm{O}_{2}$ as reaction gas and analysis on $\mathrm{m} / \mathrm{z} 47$. In all cases, data were more accurate and detection limits were sufficient from standard mode analysis and so we present these results here. Blanks and standards 440 (BHVO2 basalt) were prepared and analysed in the same manner (Supplementary Table 1). 441 For cores U1396C and U1339D, Al and Zr were determined after digestion using the same procedure as above, again alongside standard $\mathrm{BHVO} 2$ and blanks. Concentrations of these elements were determined using a Thermo X-Series ICP-MS at the University of 444 Southampton (Supplementary Table 1).

\section{$P$ depletion factors and $P$ release}

We used the GEOROC database to estimate the protolith composition of volcanic 
to non-outcrop samples, xenoliths and any mineral-specific analyses. This database was used

449 to estimate the composition of tephra prior to dissolution and diagenetic alteration. By normalising $\mathrm{P}$ to $\mathrm{Zr}$ and plotting this ratio against $\mathrm{Ti} / \mathrm{Zr}$ (elements which are largely immobile during diagenesis), the empirical relationship between the two ratios can be used to estimate

452 the original protolith composition following the method of ref. ${ }^{30}$, developed to estimate metal mobility in Cretaceous tephras (Supplementary Table 2). The linear regression representing this relationship is then used back-calculate the original composition of altered tephra (Supplementary Tables 2, 3, refs. ${ }^{58-64}$ ). These compositions, along with compositions of altered tephra, are then used to calculate depletion factors using the following equation (Equation 1):

$$
P_{D}=\frac{M_{P}^{L}}{M_{P}^{O}}=1-\frac{\left(\frac{C_{P}^{r e}}{C_{Z r}^{r e}}\right)}{\left(\frac{C_{P}^{O}}{C_{Z r}^{O}}\right)}(\text { Eq. 1) }
$$

The left side of the equation is the depletion factor, where $M_{P}^{O}$ original $\mathrm{P}$ mass in the protolith, $M_{P}^{L}$ is the loss of $\mathrm{P} . C_{P}^{r e}$ and $C_{Z r}^{r e}$ are the mass of $\mathrm{P}$ and $\mathrm{Zr}$ in tephra, and $C_{P}^{O} / C_{Z r}^{O}$ represents the ratio of $\mathrm{P}$ to $\mathrm{Zr}$ in the protolith, back-calculated from the linear regression of GEOROC data (Fig. 3, Extended Data Figures 1, 2).

\section{Estimating the extent and timing of volcanism during the Late Ordovician}

We use Monte Carlo simulations of variables associated with bentonite deposition during the Late Ordovician to estimate the size of the volcanic eruptions and associated ash deposition ${ }^{57}$. For the GICE period, we use values from published compilations of North American bentonites ${ }^{5,19}$ (Supplementary Table 4), and for the HICE we collate ages from published bentonites from China (Supplementary Table 5). For the period $455-450 \mathrm{Ma}$ (corresponding to period covering the GICE), we take the number of ash layers to be 100 based on observations ${ }^{19}$. We assume these ash layers represent eruptions of VEI 8 due to the 
location and characteristics of these bentonites, which constitute discrete centimetre-thick

471 horizons thousands of kilometres from any proposed source ${ }^{16,19}$. We assume each eruption 472 contained on average $1000 \mathrm{~km}^{3}$ erupted material ${ }^{18}$. To estimate how much erupted material 473 was ash, we use a value of $50 \%$, representing the likely proportions in Ultraplinian 474 eruptions $^{18,21}$. Since we are only interested, in the first instance, in the ash which may directly supply $\mathrm{P}$ to the ocean, we use an estimate of $50 \%$ ashfall in the ocean basins. This number is based upon estimates of ashfall which has been subducted since the Ordovician, using isopachs constructed from North American outcrops ${ }^{18}$, and paleogeographic reconstructions which indicate volcanism was linked to the opening of the Iapetus Ocean (Figure 2). For all variables used in equation 2, we apply standard deviations of all variables set at $25 \%$ of the variable mean, unless stated (Supplementary Table 6). 10,000 simulations of all variables were performed using the $\mathrm{r}$ package rtrucnnorm, and outputs were used to reconstruct likely 482 ash volumes (in $\mathrm{km}^{3}$ ).

For the period 450 - $440 \mathrm{Ma}$ (corresponding to period covering the HICE), a similar set of likely values for variables was constructed using published data on Chinese bentonite deposits $^{21}$. In this case, we use 88 ash layers as our mean, derived from the subtraction of 16 consider the uncertainty. In both cases, to estimate ash density, and the amount of $\mathrm{P}$ contained in the original 492 ashes, we use measured values from Icelandic ashfall ${ }^{32,33}$, with standard deviations derived 493 from the measurements. Using the ash volume estimates derived from these variables, and our 
depletion factors, we simulate 10,000 iterations for total $\mathrm{P}$ supply for each period (in mole P), using the following equation (Eq. 2):

$$
P \text { release }(\text { mole })=\left(\frac{V_{A s h} \times \rho_{A s h} \times P_{A s h} \times P_{D}}{30.97}\right) \times P_{o c e a n}(\text { Equation } 2)
$$

where $\mathrm{V}_{\text {Ash }}, \rho_{\text {Ash }}$ and $\mathrm{P}_{\text {Ash }}$ are the volume of ash (in $\mathrm{km}^{3}$ ), density of ash (in $\mathrm{kg} / \mathrm{m}^{3}$ ) and phosphorus content in ash (in wt \%). $\mathrm{P}_{\mathrm{D}}$ is the depletion factor of phosphorus, $\mathrm{P}_{\text {ocean }}$ is the proportion falling into the ocean and 30.97 is the molecular weight of $\mathrm{P}$, to convert from grams to moles. Such an exercise provides an absolute amount of $\mathrm{P}$ released for each period, but for modelling purposes, we must convert our total $\mathrm{P}$ supply values into flux (in mol $\mathrm{P}$ myr $1)$.

To do this, we develop a dataset of all reliably dated (i.e., excluding K-Ar or fission track dates) bentonites of Late Ordovician age from across the two primary volcanic provinces, China and North America/Baltica (Figure 2, refs. ${ }^{5,20,21,26-29,65-80}$ ). For each of the dates, we use a Monte Carlo based approach to generate 10,000 possible ages, constrained by published age and error values. We group the outputs of this exercise into $0.25 \mathrm{Myr}$ bins and produce probability density estimates for each bin (Fig. 1a, b). For each of the two volcanic provinces, we average across each bin to result in a probability density of each $0.25 \mathrm{Myr}$ period (Fig. 1c). This exercise results in two distinct peaks, representing the most likely period of volcanism for both provinces. For North America/Scandinavia, this peak is centred on 453.5 Ma. For China, the volcanic peak occurs 444.0 Ma. To represent these events in the model we then use a standard Gaussian curve with $\boldsymbol{\sigma}=0.4$, giving an event duration of around 2 Myrs. This width is informed by the duration of the carbon isotope excursions.

\section{Estimating P flux from weathering}

We estimate the spatial extent of erupted material during the Late Ordovician using an averaged value from a modelling study of Ordovician volcanism $\left(1.56 \times 10^{6} \mathrm{~km}^{2}\right.$; ref. $\left.^{60}\right)$. We 
518 then use $\mathrm{P}$ release value of $29.77 \mathrm{~kg} \mathrm{P} \mathrm{km}^{-2} \mathrm{yr}^{-1}$ as measured from basalts ${ }^{82}$. We estimate that

$51950 \%$ of the ash and lava was terrestrially emplaced based on the observations of ash

520 deposition considered previously ${ }^{18,21}$. By applying $20 \%$ errors to all of these values, we then

521 carried out 10,000 Monte Carlo simulations of each variable, before calculating the final flux

522 (in mol $\mathrm{P} \mathrm{myr}^{-1}$ ) by multiplying each iteration of each variable.

523 Biogeochemical modelling

$524 \quad$ We use the latest COPSE biogeochemical model ${ }^{39}$. We run the model baseline and add $525 P_{\text {force }}$ to the global bioavailable phosphorus weathering flux (Equation 3). This adds additional 526 phosphorus input during the Late Ordovician to the baseline model run.

$P_{\text {force }}=10^{-6} P_{\text {GICE }} \frac{\operatorname{norm}(t,-453.45,0.4)}{\operatorname{norm}(-453.45,-453.45,0.4)}+10^{-6} P_{\text {HICE }} \frac{\operatorname{norm}(t,-444,0.4)}{\operatorname{norm}(-444,-444,0.4)}($ Eq. 3$)$

Here $P_{\text {GICE }}$ and $P_{\text {HICE }}$ are the total $\mathrm{P}$ inputs from ash, weathering, and recycling in moles. Here norm is a normal function defined as norm(time,midpoint, $\boldsymbol{\sigma})$. $P_{\text {force }}$ is multiplied by 5 in some simulations to represent the additional recycling of $\mathrm{P}$ which is not captured in the COPSE model. This factor is determined by running a P-C cycling model which has an explicit representation of the shelf $\mathrm{f}^{43}$ and comparing the ratio between $\mathrm{P}$ input from weathering and overall marine $\mathrm{P}$ concentration versus the same metric in COPSE. The reader is referred to

534 Extended Data Figure 3 for the model comparison plots.

\section{Data Availability}

536 The authors declare that data supporting the findings of this study are available within the 537 article and Supplementary Information and Extended Data. All data have also been uploaded 538 to Figshare, at the following DOI addresses: http://dx.doi.org/10.6084/m9.figshare.14914893, 539 http://dx.doi.org/10.6084/m9.figshare.14914911,

540 http://dx.doi.org/10.6084/m9.figshare.14914896 and 541 http://dx.doi.org/10.6084/m9.figshare.14914890. 


\section{Code availability}

543 COPSE model code can be downloaded at https://github.com/bjwmills

544 Methods-only References

545 58. Bitschene, P. R., Mehl, K. W. \& Schmincke, H.-U. Composition and origin of marine ash

546 layers and epiclastic rocks from the Kerguelen Plateau, southern Indian Ocean (Legs 119 and 120).

547 Proc. Ocean Drill. Program, 120 Sci. Results 120, 135-149 (1992).

548 59. Schindlbeck, J. C. et al. One Million Years tephra record at IODP Sites U1436 and U1437:

549 Insights into explosive volcanism from the Japan and Izu arcs. Isl. Arc 27, e12244 (2018).

550 60. Rodehorst, U., Schmincke, H.-U. \& Sumita, M. Geochemistry and petrology of Pleistocene 551 ash layers erupted at Las Cañadas Edifice (Tenerife),. Scientific Results vol. 157 (1998).

552 61. Salisbury, M. J. et al. Deep-sea ash layers reveal evidence for large, late Pleistocene and 553 Holocene explosive activity from Sumatra, Indonesia. J. Volcanol. Geotherm. Res. 231-232, 61-71 554 (2012).

62. Derkachev, A. N. et al. Tephra layers of in the quaternary deposits of the Sea of Okhotsk:

556 Distribution, composition, age and volcanic sources. Quat. Int. 425, 248-272 (2016).

557 63. Schindlbeck, J. C. et al. Late Cenozoic tephrostratigraphy offshore the southern Central 558 American Volcanic Arc: 1. Tephra ages and provenance. Geochemistry, Geophys. Geosystems 17, $559 \quad 4641-4668(2016)$.

560 64. Allan, A. S. R., Baker, J. A., Carter, L. \& Wysoczanksi, R. J. Reconstructing the Quaternary 561 evolution of the world's most active silicic volcanic system: insights from an $\sim 1.65$ Ma deep ocean 562 tephra record sourced from Taupo Volcanic Zone, New Zealand. Quat. Sci. Rev. 27, 2341-2360 563 (2008).

564 65. Yang, S. et al. Duration, evolution, and implications of volcanic activity across the 565 Ordovician-Silurian transition in the Lower Yangtze region, South China. Earth Planet. Sci. Lett. 518, $566 \quad 13-25(2019)$. 
66. Tucker, R. D. U-Pb dating of Plinian-eruption ashfalls by the isotopic dilution method: a reliable and precise tool for time-scale calibration and biostratigraphic correlation. Geol. Soc. Amer. Abs. w/ Prog. 24, A192 (1992).

67. Oruche, N. E., Dix, G. R. \& Kamo, S. L. Lithostratigraphy of the upper Turinian - Lower Chatfieldian (upper Ordovician) foreland succession, and a U-Pb ID-TIMS date for the Millbrig volcanic ash bed in the Ottawa embayment. Can. J. Earth Sci. 55, 1079-1102 (2018).

68. Min, K., Renne, P. R. \& Huff, W. D. Ar/Ar dating of Ordovician K-bentonites in Laurentia and Baltoscandia. Earth Planet. Sci. Lett. 185, 121-134 (2001).

69. Samson, S. D., Patchett, P. J., Roddick, J. C. \& Parrish, R. R. Origin and tectonic setting of Ordovician bentonites in North America: isotopic and age constraints. Geol. Soc. Am. Bull. 101, 1175-1181 (1989).

70. Svensen, H. H., Hammer, Ø. \& Corfu, F. Astronomically forced cyclicity in the Upper Ordovician and U-Pb ages of interlayered tephra, Oslo Region, Norway. Palaeogeogr. Palaeoclimatol. Palaeoecol. 418, 150-159 (2015).

71. Bauert, H. et al. New U-Pb zircon ages of the Sandbian (Upper Ordovician) 'Big K-bentonite' in Baltoscandia (Estonia and Sweden) by LA-ICPMS. GFF 136, 30-33 (2014).

72. Compston, W. \& Williams, I. S. Ion probe ages for the British Ordovician and Silurian stratotypes. in Global perspectives on Ordovician geology (eds. Webby, B. D. \& Laurie, J. R.) 59-67 (1992). the Lower Silurian Longmaxi Formation on the Yangtze Platform, South China: Implications for stratigraphic correlation and environmental change. Chem. Geol. 509, 249-260 (2019). Earth Sci. 51, 493-498 (2008). 
593 the uppermost part of the Ordovician Wufeng Formation in the Haoping section,Taoyuan,Hunan.

594 Sediment. Tethyan Geol. 4, 597 (2012).

595 76. Yang, S. et al. Constraints on the accumulation of organic matter in Upper Ordovician-lower 596 Silurian black shales from the Lower Yangtze region, South China. Mar. Pet. Geol. 120, 104544 597 (2020).

598 77. Ge, X. et al. Mineralogical and geochemical characteristics of K-bentonites from the Late 599 Ordovician to the Early Silurian in South China and their geological significance. Geol. J. 54, 514-528 600 (2019).

601 78. Zheng, B. et al. Nature of the Late Ordovician-Early Silurian Xiaohe section, Hunan-Hubei 602 area, South China: implications for the Kwangsian Orogeny. Int. Geol. Rev. 62, 1262-1272 (2020).

603 79. Kunk, M. J., Sutter, J., Obradovich, J. D. \& Lanphere, M. A. Age of biostratigraphic horizons 604 within the Ordovician and Silurian systems. Geol. Soc. Mem. 10, 89-92 (1985).

605 80. Tucker, R. D., Krogh, T. E., Ross, R. J. \& Williams, S. H. Time-scale calibration by high606 precision UPb zircon dating of interstratified volcanic ashes in the Ordovician and Lower Silurian 607 stratotypes of Britain. Earth Planet. Sci. Lett. 100, 51-58 (1990).

608 81. Lefebvre, V., Servais, T., François, L. \& Averbuch, O. Did a Katian large igneous province 609 trigger the Late Ordovician glaciation?. A hypothesis tested with a carbon cycle model. Palaeogeogr. 610 Palaeoclimatol. Palaeoecol. 296, 310-319 (2010).

611 82. Hartmann, J., Moosdorf, N., Lauerwald, R., Hinderer, M. \& West, A. J. Global chemical 612 weathering and associated p-release - the role of lithology, temperature and soil properties. Chem. 613 Geol. 363, 145-163 (2014). 


\title{
Late Ordovician climate change and extinctions driven by elevated volcanic nutrient
} supply

Jack Longman ${ }^{1,2, *}$, Benjamin J. W. Mills ${ }^{3}$, Hayley R. Manners ${ }^{4,5}$, Thomas M. Gernon ${ }^{4}$ and Martin R. Palmer ${ }^{4}$

${ }^{1}$ Marine Isotope Geochemistry, Institute for Chemistry and Biology of the Marine Environment (ICBM), University of Oldenburg, PO Box 2503, 26111 Oldenburg, Germany.

${ }^{2}$ School of Geography and the Environment, University of Oxford, South Parks Road, Oxford, OX1 3QY, UK.

${ }^{3}$ School of Earth and Environment, University of Leeds, Leeds LS2 9JT, UK.

${ }^{4}$ School of Ocean and Earth Sciences, University of Southampton, Southampton, SO14 3ZH, 2 UK.

${ }^{5}$ School of Geography, Earth and Environmental Sciences, University of Plymouth, Plymouth, PL4 8AA, UK.

\section{${ }^{*}$ Corresponding Author: jack.longman@uni-oldenburg.de}

\begin{abstract}
The Late Ordovician ( 459-444 million years ago) was characterised by global cooling, glaciation and severe mass extinction. These events may have been driven by increased delivery of the nutrient phosphorus $(P)$ to the ocean, and associated increases in marine productivity, but it is not clear why this occurred in the two pulses identified in the geological record. We link both cooling phases, and the extinction, to volcanic eruptions through marine deposition of nutrient-rich ash and the weathering of terrestrially emplaced ash and lava. We then reconstruct the influence of Late Ordovician volcanic $\mathbf{P}$ delivery on the marine system by coupling an estimate of bioavailable phosphate supply
\end{abstract}


(derived from a depletion and weathering model) to a global biogeochemical model. Our model compares volcanic ash $P$ content in marine sediments before and after alteration to determine depletion factors, and we find good agreement with observed carbon isotope and reconstructed temperature shifts. Hence, massive volcanism can drive substantial global cooling on million-year timescales due to $\mathbf{P}$ delivery associated with long-term weathering of volcanic deposits, offsetting the transient warming of greenhouse gas emission associated with volcanic eruptions. Such longer-term cooling and potential for marine eutrophication may be important for other volcanism-driven global events.

\section{Main Text}

The Late Ordovician mass extinction (LOME) occurred in two phases, and in terms of species loss was the second greatest extinction event in Earth's history ${ }^{1-3}$. The Late Ordovician is characterised by a number of carbon isotope excursions (CIEs), with two globallyrepresented, the Guttenburg (GICE) at $\sim 454 \mathrm{Ma}$, and Hirnantian (HICE) at $\sim 445 \mathrm{Ma}^{4}$. The GICE coincides with global cooling, and the beginning of the HICE is associated with widespread glaciation, with the cooling periods generally implicated in instigating the $\mathrm{LOME}^{1,5-7}$

The primary driver behind the CIEs and associated cooling is uncertain. One possibility is that the emergence of early nonvascular land plants amplified terrestrial weathering and increased the delivery of the key limiting nutrient phosphorus to the oceans ${ }^{8}$. Greater availability of phosphorus increases marine productivity and organic carbon burial, driving a reduction in atmospheric $\mathrm{CO}_{2}$ and a positive excursion in carbonate $\delta^{13} \mathrm{C}$ (ref. ${ }^{9}$ ). Other proposals include an increasing fraction of eukaryotic marine production strengthening the biological pump ${ }^{10}$, and increased tropical weathering resulting from orogenesis augmenting the supply of phosphorus to the oceans ${ }^{11}$. 
The concept that Late Ordovician cooling was driven by organic carbon burial is supported by observations ${ }^{12}$, but why this occurred in two distinct pulses during the GICE and HICE is unclear. This pulsing may have arisen from early plants colonising new terranes ${ }^{8}$, but there is little evidence for this, although poor fossil preservation cannot be ruled out ${ }^{13}$.

Further, the pace of early plant evolution remains highly uncertain ${ }^{13}$ and there is no evidence that eukaryotic evolution, or tropical uplift, occurred in distinct pulses. Existing global biogeochemical models cannot reliably reproduce the Hirnantian glaciation (or isotope excursions) associated with the HICE when based on known long-term tectonic cycles of uplift and degassing, and the positioning of the continents ${ }^{9}$, even though these models can accurately reproduce the Permo-Carboniferous and late Cenozoic icehouses ${ }^{9}$. This suggests that the Hirnantian icehouse was driven by some climatic forcing mechanism currently not well-represented in these models.

Given the potential association between volcanism and global climate change ${ }^{14,15}$, we explore the concept that Late Ordovician marine productivity and cooling episodes were directly related to subaerial volcanic activity. The Late Ordovician was characterised by extensive volcanic eruptions, preserved in the sedimentary record as bentonites ${ }^{16,17}$. These bentonites represent some of the largest volcanic eruptions in Earth's history, with estimates indicating some of the better studied events (Millbrig, Deicke and Kinnekulle) erupted $\geq 1000$ $\mathrm{km}^{3}$ of pyroclastic material ${ }^{18}$. In addition, there are hundreds of spatially extensive bentonites of Late Ordovician (459 - $444 \mathrm{Ma})$ age preserved across North America ${ }^{19}$, Northern Europe ${ }^{20}$, and China ${ }^{16,21}$, prompting suggestions of a causal link between volcanism and global cooling during this period ${ }^{3,14,17}$. Most recently, several studies have employed the total organic carbon to mercury ratio $(\mathrm{TOC} / \mathrm{Hg})$, to directly link volcanic $\mathrm{Hg}$ emission to Late Ordovician climatic change (e.g. refs. ${ }^{22,23}$ ). However, it remains uncertain whether cooling was driven by rapid sulfate emissions, through the immediate weathering of ash and lava, or by longer-term 
weathering of volcanic arcs and uplifted terranes ${ }^{17,23}$, a problem compounded by poorly constrained volcanic fluxes.

Volcanism may cool the climate on non-transitory timescales due to enhanced productivity and organic carbon preservation ${ }^{24}$, with one of the key drivers being enhanced $\mathrm{P}$ supply derived from leaching of volcanic ash ${ }^{25}$. It is not currently clear how much P may have been supplied from ash during the Late Ordovician, or how input of volcanic P may have influenced the marine environment. To answer these questions, we compile global data on $\mathrm{P}$ depletion in tephra layers today, as a method of quantifying P release to the ocean during ash deposition and diagenesis. We couple our estimates of $\mathrm{P}$ flux to a global biogeochemical model to investigate the potential impact of such nutrient supply to the Late Ordovician marine carbon cycle.

\section{Timing and extent of volcanism during the Late Ordovician}

To estimate timing of volcanic activity, we compile $43 \mathrm{Ar}-\mathrm{Ar}$ and $\mathrm{U}-\mathrm{Pb}$ dates from North American and Scandinavian bentonites (Fig. 1a), and 24 dates from Chinese bentonites of Late Ordovician age (Fig. 1b). Our reconstruction indicates that bentonite deposition occurred in two discrete pulses (Fig. 1c), corresponding to the eruption of two geographically distinct volcanic provinces (Figure 2). The first pulse represents North American/Scandinavian volcanism and is well-constrained, with the greatest depositional intensity occurring between 454.5 - 453 Ma, peaking at 453.5 Ma (Fig. 1c). This peak primarily represents highly-precise measurements of the North American "big" bentonites, the Deicke and Millbrig, 5,26 , and the Grimstorp bentonite ${ }^{26}$. A slightly earlier peak is also apparent (c. $456.5 \mathrm{Ma}$ ), representing potentially uncertain estimates of the Kinnekulle bentonite $\operatorname{age}^{27}$, and other unnamed bentonites from Oslo $^{20}$ (see Supplementary Table 4). Chinese bentonite ages exhibit more spread, with fewer highly precise dates (Fig. 1c). Our compilation suggests the most intense volcanism in the China region occurred between 445.25 
- 442.5 Ma, with a peak at about $444 \mathrm{Ma}$ (Fig. 1c), corresponding to some of the most accurate dates from outcrop in the south-western Yunnan province ${ }^{28}$, and central Hubei province $^{29}$. These two volcanic pulses correspond well to the two primary carbon isotope excursions of the Late Ordovician, the GICE and HICE, and may thus support a link between volcanism and climate change.

\section{$P$ release during ash deposition, diagenesis and weathering}

To investigate this hypothesis, we estimate the amount of $\mathrm{P}$ which may have been supplied by the two main pulses of volcanism. To estimate the percentage of $\mathrm{P}$ released during ash deposition and diagenesis, altered ash compositions are compared to unaltered protolith compositions to estimate metal mobility ${ }^{30,31}$, using protolith data from the GEOROC database (http://georoc.mpch-mainz.gwdg.de) and our data from altered tephras (see Methods). Specifically, marine sediment-hosted tephras from the Lesser Antilles and the Aleutian arcs have been analysed and compared to similar data from eight additional modern volcanic provinces (Fig. 1). In addition to direct input of P from volcanic ash deposition, the emplacement and subsequent terrestrial weathering of extensive ash beds would have led to a secondary source of $\mathrm{P}$ to the oceans. The scale of this $\mathrm{P}$ flux has been estimated from a Monte Carlo simulation of inputs using published variables including the number, and scale of eruptions (Methods, Extended Data Figures 1, 2).

Depletion factors indicate between $31 \%$ (mean) and $48 \%$ (median) of the P originally hosted in tephra is lost during early diagenesis (Fig. 3). The potential scale of this process is calculated in the modern oceans, using an average of $1.14 \pm 0.6 \mathrm{~km}^{3}$ ash deposited per year, with $70 \pm 7.5 \%$ falling into the ocean ${ }^{31}$, an ash density of $1400 \pm 130 \mathrm{~kg} / \mathrm{m}^{3}\left(\right.$ ref. $^{32}$ ), and an original P content in tephra of $0.41 \pm 0.19 \mathrm{wt} \%\left(\right.$ ref. $\left.^{33}\right)$. For each variable, a Monte Carlobased approach is applied, using the average and standard deviation to develop 10,000 possible iterations of each variable. From this calculation, the most likely annual $\mathrm{P}$ flux from 


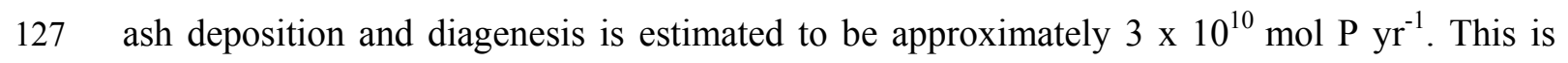

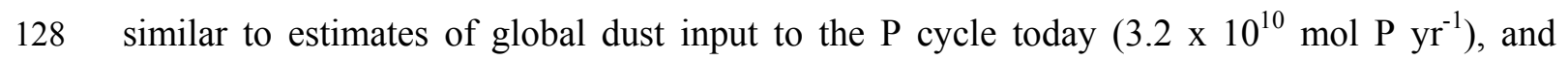
129 exceeds the dissolved riverine input $\left(0.6-1.1 \times 10^{10} \mathrm{~mol} \mathrm{P} \mathrm{yr}^{-1} ;\right.$ ref. $\left.^{34}\right)$. Present-day volcanism

130 is thought to be far smaller in scale than in periods such as the Ordovician ${ }^{35,36}$. Therefore, 131 enhanced $\mathrm{P}$ supply tied to volcanism likely played an even more important role in 132 biogeochemical cycles of $\mathrm{P}$ during the Ordovician.

\section{Impact of volcanic ash supply on Late Ordovician climate}

134 The depletion factors and estimates of ash supply during the Late Ordovician can be used to quantify the scale of $\mathrm{P}$ supply during the two studied events. For the GICE, our simulations indicate a mean of $2.29 \times 10^{15}$ mol P (Fig. 4), which increases to $6.49 \times 10^{15} \mathrm{~mol}$ $\mathrm{P}$ in the upper estimates of the simulations $\left(95^{\text {th }}\right.$ percentile). For the volcanic episode covering of $8.24 \times 10^{15} \mathrm{~mol} \mathrm{P}\left(95^{\text {th }}\right.$ percentile) (Fig. 4). In addition to ash falling into the ocean, the impact of erosion of terrestrially emplaced ash and lava on the $\mathrm{P}$ cycle is considered by estimating weathering fluxes of $\mathrm{P}$ (Methods). Newly emplaced ashes and basaltic rocks weather rapidly ${ }^{37,38}$, such that in Earth's modern configuration, despite representing only 3 $5 \%$ of land area, chemical weathering of basalt contributes $\sim 30 \%$ of the total $\mathrm{CO}_{2}$ consumption by silicate weathering ${ }^{37,38}$. Our approach to quantifying the impact of this process results in a mean additional (riverine) $\mathrm{P}$ flux from weathering of $7.51 \times 10^{14} \mathrm{~mol} \mathrm{P}$ $\mathrm{Myr}^{-1}$ in the millennia after emplacement (Fig. 4c), with an upper estimate of $1.23 \times 10^{15} \mathrm{~mol}$ $\mathrm{P} \mathrm{Myr}^{-1}$ (95 ${ }^{\text {th }}$ percentile), providing another source of bioavailable $\mathrm{P}$ to the ocean system.

The impact of this level of volcanic nutrient supply on Ordovician climate is estimated using the COPSE global biogeochemical model ${ }^{39}$. The GICE and HICE P inputs are represented by Gaussian functions with their maxima at the times of highest depositional intensity noted above (i.e., 453.5 and $444 \mathrm{Ma}$ ) and with a width of 2 Myrs, constrained in part 
152 by the duration of the carbon isotope excursions. The total $\mathrm{P}$ input is calculated for both the 153 means and $95^{\text {th }}$ percentiles and is summed from the P depletion model and weathering inputs. 154 A further factor is also added into the $\mathrm{P}$ delivery calculation to represent the recycling of $\mathrm{P}$ 155 from sediments, because $\mathrm{P}$ loading and eutrophication in marginal settings leads to a 156 substantial recycling flux of $\mathrm{P}$ from the sediments ${ }^{40}$, due to the increase in anaerobic 157 processing of organic matter and the scarcity of Fe(III) phases that scavenge P. The COPSE 158 model does not represent these feedbacks well, because it has a well-mixed global ocean and 159 no consideration of continental margins, with substantial recycling of $\mathrm{P}$ relying on 160 eutrophication of the global ocean rather than productive shelves and slope environments 161 alone ${ }^{39}$. This is relevant to the Ordovician, a time when sea level was perhaps $300 \mathrm{~m}$ higher 162 than present ${ }^{41}$, with extensive shelf environments ${ }^{42}$. Hence, parallel experiments were run to 163 determine the degree to which P recycling is dampened in COPSE versus a published P cycle 164 model in which the shelves are considered separately (see Methods, ref. $^{43}$ ). We conclude that 165 a 5-fold larger $\mathrm{P}$ input is required in COPSE to produce the same spike in marine $\mathrm{P}$ 166 concentration observed in the multi-box model (Extended Data Figure 3). Thus, P inputs in 167 the additional COPSE simulations are increased 5-fold to represent both the initial input and 168 the additional recycling of $\mathrm{P}$. The large size of this factor is related to the relatively small size 169 of the ocean shelves (as a fraction of the whole ocean) compared to their disproportionately 170 large contribution to organic matter burial.

171 An important parameter in COPSE is the degree to which land plants amplify continental weathering rates. This value is poorly constrained and is typically varied in sensitivity analyses between around 2- and 7-fold, giving a wide range of possible background $\mathrm{CO}_{2}$ concentrations for the early Palaeozoic ${ }^{44}$. We choose a factor 2 enhancement for the model runs in this work, which gives a relatively low background Ordovician $\mathrm{CO}_{2}$ concentration of around $1000 \mathrm{ppm}$, consistent with more recent proxy data ${ }^{45}$. Other than the 177 new $\mathrm{P}$ inputs and choice of biotic weathering parameter, the model remains identical to the 
178 long-term baseline shown in ref. ${ }^{39}$. Figure 5 shows the model outputs for atmospheric $\mathrm{CO}_{2}$, 179 average surface temperature, marine anoxia, and the $\delta^{13} \mathrm{C}$ of new sedimentary carbonates. The 180 model outputs show that the P release from volcanic ash deposition and weathering, combined 181 with the recycling of $\mathrm{P}$ from sediments, is sufficient to cause large-scale changes in climate 182 and biogeochemistry as observed in the geological record ${ }^{10,14}$. In the " $95^{\text {th }}$ percentile + 183 recycling" input scenario, carbon isotope excursions of $\sim 3 \%$ and $\sim 4 \%$ are predicted, which 184 are synchronous with the GICE and HICE, respectively, and are of similar magnitude. In this 185 scenario, maximum global cooling at the $\mathrm{HICE}$ is around $3^{\circ} \mathrm{C}$, and a global average surface temperature of below $15^{\circ} \mathrm{C}$ is reached at the nadir. These temperature predictions are in line with clumped isotope thermometry which suggests the Hirnantian icehouse was relatively short lived and represented a similar global average temperature to recent Pleistocene glaciation $^{6,46}$.

The extent of marine anoxia increases during the $\mathrm{P}$ input events in the model, although given the global well-mixed ocean in the model, shelf anoxia would be expected to increase by a larger fraction than the global ocean. This is against a backdrop of marine oxygenation through the Ordovician and Silurian predicted by $\mathrm{COPSE}^{39}$. One of the major features of the HICE in the geological record is the widespread formation of organic-rich shales, in particular in China ${ }^{47,48}$, potentially linked to widespread ocean anoxia ${ }^{10,49}$. In COPSE, the relative increase in anoxia is much larger during the HICE - close to a doubling in the " $95^{\text {th }}$ percentile + recycling" scenario.

\section{Implications for the LOME}

Our model results suggest that volcanic ash diagenesis and weathering of erupted products likely played a key role in the Late Ordovician Earth system. In order to reproduce the magnitude of Earth system change, we require that these inputs are at the $95^{\text {th }}$ percentile of our analysis. However, given the relatively sparse nature of the geological record of the 
Palaeozoic, and the conservative approach utilised here to derive estimates of $\mathrm{P}$ supply from

204 ash (Methods), we stress that our analysis likely underestimates the number of volcanic

205 events. This is supported by the close comparison between the model output of the "95th

206 percentile + recycling" input scenario and proxy data (Fig. 5, ref. ${ }^{50}$ ). Our results may explain

207 several features of the LOME, which do not follow trends associated with other mass

208 extinctions, in particular their link to cooling, rather than warming. Volcanic activity has been

209 invoked as the driver behind a number of short-term climatic upheavals and mass

210 extinctions $^{51}$, including those at the end of the Permian ${ }^{52}$ and in the Triassic periods ${ }^{53}$,

211 resulting in the rapid fluctuations between icehouse and greenhouse conditions known to

212 stress faunas and drive biodiversity $\operatorname{loss}^{3,52}$.

For the Late Ordovician, it appears that the long-term nature of nutrient supply from weathering of eruptive products such as volcanic ash plays a more dominant role than the medium-term warming associated with $\mathrm{CO}_{2}$ injection. When comparing to climatic change, it is clear that the first stepped decrease in faunal diversity occurred soon after the GICE, with two further decreases occurring temporally close to the $\mathrm{HICE}^{3,54}$. Our approach considers many eruptions to estimate nutrient supply on a coarse scale. The super-eruptions represented by bentonites would likely have led to initial cooling (due to injection of stratospheric aerosols), followed by warming (from $\mathrm{CO}_{2}$ injection), before cooling because of increases in nutrient supply and associated productivity levels. The warming/cooling cycles this scenario represents are purportedly dangerous for organisms, with biodiversity loss occurring when temperatures fall outside the optimal window ${ }^{3}$, potentially explaining the LOME initiation. Due to their global nature, we focus on the HICE and GICE, and only model two P pulses. However, bentonite ages suggest that multiple eruptions occurred between the two largest volcanic episodes and CIEs (Fig. 1), which may have led to transient local CIEs, such as those reported in the Scandinavian sections ${ }^{7}$. 
In addition to releasing nutrients, it is possible that other toxic metals are also released

229 during ash alteration and diagenesis ${ }^{25}$. During the Hirnantian glaciation and the HICE, there is

230 evidence for metal-induced malformations in fossil plankton assemblages ${ }^{55}$. Further, volcanic

231 ash may lead to the formation of large-scale anoxic conditions below deposited blankets ${ }^{24}$,

232 which may have further enhanced redox-based recycling of toxic metals ${ }^{55}$ and led to the

233 deposition of widespread black shales ${ }^{47}$. Using the evidence presented here, we conclude that

234 the pulsed nature of global cooling at this time appears to be a result of the eruption of two

235 distinct volcanic provinces, one in what is now North America and the Baltic, and one in what

236 is now Southern China. Further, our models suggest that the deposition of extensive ash

237 blankets and weathering of lavas emplaced during Late Ordovician volcanism, supplied

238 sufficient $\mathrm{P}$ to drive global cooling, glaciation, and the LOME.

\section{Acknowledgements}

240 This work was funded by NERC grant NE/K00543X/1, "The role of marine diagenesis of 241 tephra in the carbon cycle". B.J.W.M. acknowledges support from NERC grant 242 NE/S009663/1. T.M.G. acknowledges support of NERC grant NE/R004978/1, and funding 243 from the Alan

244 Turing Institute (EP/N510129/1). We are grateful for comments from Christian Rasmussen 245 and the anonymous reviewer(s), which helped to improve the manuscript. We are grateful to 246 staff of the IODP Gulf Coast Repository and IODP Kochi Core Repository for their assistance 247 during sampling of cores U1396C and U1339D, respectively.

\section{Author Contributions}

249 J.L., T.M.G. and M.R.P. conceived this research. J.L. and H.R.M. completed the laboratory 250 analyses. B.J.W.M. completing the modelling and J.L. compiled and analysed the data. J.L. 
and B.J.W.M. created the figures. J.L. and B.J.W.M. wrote the manuscript, with input from

252 T.M.G., H.R.M. and M.R.P.

253 Competing Interests

254 The authors declare no competing interests.

255 Corresponding Author

256 All correspondence and request for materials should be addressed to Jack Longman 257 (jack.longman@uni-oldenburg.de)

\section{Figure Captions}

259 Figure 1: Compilation of Late Ordovician bentonite ages from North America and

260 China. Bentonites ages in North America/Scandinavia (a), and China (b). Each age is

261 represented by a probability density curve derived from published mean and standard

262 deviation, from which 10,000 Monte Carlo simulations were completed and binned at 0.25

263 Myr intervals to attain probability densities of the eruption occurring in each bin. Colours

264 correspond to the studies from which each age is obtained. c, Average probability densities

265 for each 0.25 Myr bin, for the North American (blue) and Chinese bentonites (red). Vertical

266 lines indicate the bin in which bentonite deposition is most likely. (See Supplementary Tables

2674 and 5 for references).

268 Figure 2: Paleogeographic reconstruction for the Late Ordovician at c. 450 Ma (Katian).

269 Marked with ellipses are the two volcanic provinces investigated in this study, with blue

270 ellipses representing the North American and Scandinavian province, and a green ellipse to

271 represent the Chinese province. The base map was constructed using the plate tectonic

272 reconstructions from ref. ${ }^{56}$ and is based partly on ref $^{57}$.Figure 3: Box and whisker diagrams

273 of phosphorus depletion, an indicator of the amount of phosphorus lost to the ocean,

274 from ten present-day representative volcanic provinces (a). Boxes are defined between the 
275 first and third quartile (the interquartile range, IQR), with minimum and maximum whiskers

276 representative of 1.5 times the IQR. Also shown is a map of each volcanic province used for

277 this reconstruction (b), with the provinces identified by numbers given in panel (a).Figure 4:

278 Monte Carlo simulations of phosphorus supply from volcanic weathering during the

279 Late Ordovician, with variable distributions defined by our ash depletion and

280 weathering model. (a) and (b) represent P supply from ash deposition and diagenesis. In both

281 panels, the total ash volume is presented along the $\mathrm{x}$-axis, with total phosphorus supply on the

282 y-axis. Each Monte Carlo simulation is indicated by a circle, with the colour indicating the

283 depletion factor. (c) Estimate of P flux resulting from weathering of terrestrial volcanic matter

284 (y-axis), plotted against the area covered by this ash and lava. Again, each simulation is

285 indicated by a filled circle, with the colour denoting the rate of phosphorus supply.

Figure 5. Biogeochemical model outputs for impacts of volcanism during the GICE and HICE. COPSE model baseline runs ${ }^{39}$ plus $\mathrm{P}$ supply from ash. a, Grey lines show the P input Gaussian functions (see text). The P input magnitude follows the mean or $95^{\text {th }}$ percentiles of the values derived for ash supply and weathering combined, with or without recycling of $\mathrm{P}$ from sediments (see main text). b, Modelled $\delta^{13} \mathrm{C}$ of carbonates (with colours defined in panel e) compared to data ${ }^{50}$ (yellow circles). c, Modelled atmospheric $\mathrm{CO}_{2}$. d, Modelled global average surface temperature. e, Degree of marine anoxia (represented as the modelled proportion of anoxic seafloor). Solid lines show the same simulations as the dashed lines, but with additional $\mathrm{P}$ input to represent sedimentary recycling of $\mathrm{P}$ (see text).

\section{References}

1. Harper, D. A. T., Hammarlund, E. U. \& Rasmussen, C. M. Ø. End Ordovician extinctions: A coincidence of causes. Gondwana Res. 25, 1294-1307 (2014).

2. Bambach, R. K., Knoll, A. H. \& Wang, S. C. Origination, extinction, and mass depletions of marine diversity. Paleobiology 30, 522-542 (2004). 
301 Paleozoic marine radiations paused by Late Ordovician extinctions. Proc. Natl. Acad. Sci. U. S. A. $302116,7207-7213(2019)$.

303 4. Bergström, S. M., Schmitz, B., Saltzman, M. R. \& Huff, W. D. The Upper Ordovician 304 Guttenberg $813 \mathrm{C}$ excursion (GICE) in North America and Baltoscandia: Occurrence, 305 chronostratigraphic significance, and paleoenvironmental relationships. Geol. Soc. Am. Spec. Pap. $306466,37-67(2010)$.

307 5. Metzger, J. G., Ramezani, J., Bowring, S. A. \& Fike, D. A. New age constraints on the 308 duration and origin of the Late Ordovician Guttenberg $\delta^{13} \mathrm{C}_{\text {carb }}$ excursion from high-precision U-Pb 309 geochronology of K-bentonites. GSA Bull. (2020) doi:10.1130/B35688.1.

310 6. Finnegan, S. et al. The magnitude and duration of late Ordovician-early Silurian glaciation. 311 Science. 331, 903-906 (2011).

312 7. Ainsaar, L. et al. Middle and Upper Ordovician carbon isotope chemostratigraphy in 313 Baltoscandia: A correlation standard and clues to environmental history. Palaeogeogr. Palaeoclimatol. 314 Palaeoecol. 294, 189-201 (2010).

315 8. Lenton, T. M., Crouch, M., Johnson, M., Pires, N. \& Dolan, L. First plants cooled the 316 Ordovician. Nat. Geosci. 5, 86-89 (2012).

317 9. Mills, B. J. W. et al. Modelling the long-term carbon cycle, atmospheric CO2, and Earth 318 surface temperature from late Neoproterozoic to present day. Gondwana Research vol. 67 172-186 319 (2019).

320 10. Shen, J. et al. Improved efficiency of the biological pump as a trigger for the Late Ordovician 321 glaciation. Nat. Geosci. 11, 510-514 (2018).

322 11. Swanson-Hysell, N. L. \& Macdonald, F. A. Tropical weathering of the Taconic orogeny as a 323 driver for Ordovician cooling. Geology 45, 719-722 (2017). 
324 12. Bartlett, R. et al. Abrupt global-ocean anoxia during the Late Ordovician-early Silurian 325 detected using uranium isotopes of marine carbonates. Proc. Natl. Acad. Sci. U. S. A. 115, 5896-5901 326 (2018).

327 13. Morris, J. L. et al. The timescale of early land plant evolution. Proc. Natl. Acad. Sci. U. S. A. 328 115, E2274-E2283 (2018).

329 14. Buggisch, W. et al. Did intense volcanism trigger the first Late Ordovician icehouse? Geology $330 \quad 38,327-330(2010)$.

331 15. Herrmann, A. D., Leslie, S. A. \& MacLeod, K. G. Did intense volcanism trigger the first Late 332 Ordovician icehouse?: COMMENT. Geology 39, e237-e237 (2011).

333 16. Huff, W. D., Bergström, S. M. \& Kolata, D. R. Ordovician explosive volcanism. Geol. Soc. 334 Am. Spec. Pap. 466, 13-28 (2010). 17. Tao, H., Qiu, Z., Lu, B., Liu, Y. \& Qiu, J. Volcanic activities triggered the first global cooling event in the Phanerozoic. J. Asian Earth Sci. 104074 (2019) doi:10.1016/j.jseaes.2019.104074. Ordovician volcanic ash falls in North America and Europe: Dimensions, emplacement and postemplacement characteristics. J. Volcanol. Geotherm. Res. 73, 285-301 (1996). (Sandbian-Katian) K-bentonites of eastern North America. Bull. Geol. Soc. Am. 127, 1259-1274 342 (2015). Ordovician (Sandbian) K-bentonites in Oslo, Norway. Palaeogeogr. Palaeoclimatol. Palaeoecol. 520, 203-213 (2019). doi:10.1144/jgs2020-049. 
350 Volcanic Trigger for the Late Ordovician Mass Extinction Event: An Example from a Deep Shelf of 351 the Peri-Baltic Region. Sci. Rep. 9, 1-11 (2019).

352 23. Jones, D. S., Martini, A. M., Fike, D. A. \& Kaiho, K. A volcanic trigger for the late 353 Ordovician mass extinction? Mercury data from south China and Laurentia. Geology 45, 631-634 354 (2017).

355 24. Longman, J., Palmer, M. R., Gernon, T. M. \& Manners, H. R. The role of tephra in enhancing 356 organic carbon preservation in marine sediments. Earth-Science Rev. 192, 480-490 (2019).

357 25. Jones, M. T. \& Gislason, S. R. Rapid releases of metal salts and nutrients following the 358 deposition of volcanic ash into aqueous environments. Geochim. Cosmochim. Acta 72, 3661-3680 359 (2008).

360 26. Sell, B., Ainsaar, L. \& Leslie, S. Precise timing of the Late Ordovician (Sandbian) super361 eruptions and associated environmental, biological, and climatological events. J. Geol. Soc. London. $362170,711-714(2013)$.

363 27. Tucker, R. D. \& McKerrow, W. S. Early Paleozoic chronology: a review in light of new U-Pb 364 zircon ages from Newfoundland and Britain. Can. J. Earth Sci. 32, 368-379 (1995).

365 28. Ling, M. X. et al. An extremely brief end Ordovician mass extinction linked to abrupt onset of 366 glaciation. Solid Earth Sci. 4, 190-198 (2019).

367 29. Du, X. et al. Was volcanic activity during the Ordovician-Silurian transition in South China 368 part of a global phenomenon? Constraints from zircon $\mathrm{U}-\mathrm{Pb}$ dating of volcanic ash beds in black 369 shales. Mar. Pet. Geol. 114, 104209 (2020).

370 30. Lee, C.-T. A. et al. Volcanic ash as a driver of enhanced organic carbon burial in the 371 Cretaceous. Sci. Rep. 8, 4197 (2018).

372 31. Longman, J., Palmer, M. R., Gernon, T. M. \& Manners, H. R. Subaerial volcanism is a major 373 contributor to oceanic iron and manganese cycles. In Review. 

of Eyjafjallajökull, Iceland. Sci. Rep. 2, 572 (2012). dynamics during the Eyjafjallajökull 2010 eruption. Am. Mineral. 102, 1173-1186 (2017). (2007).

35. Cao, W., Lee, C. T. A. \& Lackey, J. S. Episodic nature of continental arc activity since 750 Ma: A global compilation. Earth Planet. Sci. Lett. 461, 85-95 (2017).

36. Mills, B. J. W., Scotese, C. R., Walding, N. G., Shields, G. A. \& Lenton, T. M. Elevated CO2 degassing rates prevented the return of Snowball Earth during the Phanerozoic. Nat. Commun. 8, 1-7 (2017).

37. Dessert, C., Dupré, B., Gaillardet, J., François, L. M. \& Allègre, C. J. Basalt weathering laws and the impact of basalt weathering on the global carbon cycle. Chem. Geol. 202, 257-273 (2003). global climate and the 87Sr/86Sr ratio of seawater. Earth Planet. Sci. Lett. 188, 459-474 (2001). during the Neoproterozoic and Palaeozoic. Interface Focus 10, 20190137 (2020). circulation. Biogeosciences 4, 155-171 (2007). accumulation in shallow-shelf and deep-marine settings. J. Geol. 110, 75-87 (2002). property of global biogeochemical cycling. Science . 366, 1333-1337 (2019). 

(1991).

45. Witkowski, C. R., Weijers, J. W. H., Blais, B., Schouten, S. \& Sinninghe Damsté, J. S. Molecular fossils from phytoplankton reveal secular PCO2 trend over the phanerozoic. Sci. Adv. 4, eaat4556 (2018).

46. Goldberg, S. L., Present, T. M., Finnegan, S. \& Bergmann, K. D. A high-resolution record of early Paleozoic climate. Proc. Natl. Acad. Sci. 118, (2021).

47. Zou, C. et al. Organic-matter-rich shales of China. Earth-Science Reviews vol. 189 51-78 (2019).

48. Su, W. et al. K-bentonite, black-shale and flysch successions at the Ordovician-Silurian transition, South China: Possible sedimentary responses to the accretion of Cathaysia to the Yangtze Block and its implications for the evolution of Gondwana. Gondwana Res. 15, 111-130 (2009). Hirnantian glaciation. Palaeogeogr. Palaeoclimatol. Palaeoecol. 276, 182-195 (2009). (eds. Gradstein, F. M., Ogg, J.., Schmitz, M. D. \& Ogg, G, M.) 207-232 (Elsevier, 2012). doi:10.1016/B978-0-444-59425-9.00011-1.

51. Sobolev, S. V. et al. Linking mantle plumes, large igneous provinces and environmental catastrophes. Nature 477, 312-316 (2011). sulfur outgassing. Nat. Geosci. 11, 949-954 (2018). Triassic mass extinction and flood basalt volcanism at the $100 \mathrm{ka}$ level. Geology 38, 387-390 (2010). biodiversity. Science . 367, 272-277 (2020). 
55. Vandenbroucke, T. R. A. et al. Metal-induced malformations in early Palaeozoic plankton are harbingers of mass extinction. Nat. Commun. 6, (2015).

56. Merdith, A. S. et al. Extending full-plate tectonic models into deep time: Linking the Neoproterozoic and the Phanerozoic. Earth-Science Rev. 214, 103477 (2021). Gondwana Res. (2020) doi:10.1016/j.gr.2020.09.008.

\section{Methods}

\section{Major and trace element geochemistry}

were analysed for their phosphorus content. Tephras were identified visually, and microscopically, in core 1339D and through their low $\mathrm{CaCO}_{3}$ content in U1396C. P was analysed in tephra layers after mixed acid $\left(\mathrm{HNO}_{3}-\mathrm{HCl}-\mathrm{HF}\right)$ bench-top digestion. Samples were then analysed on a Perkin Elmer 2000B at the University of Oxford. Analysis was completed in both standard mode $(\mathrm{m} / \mathrm{z} 31)$ and in reaction mode, with $\mathrm{O}_{2}$ as reaction gas and analysis on $\mathrm{m} / \mathrm{z} 47$. In all cases, data were more accurate and detection limits were sufficient from standard mode analysis and so we present these results here. Blanks and standards 440 (BHVO2 basalt) were prepared and analysed in the same manner (Supplementary Table 1). 441 For cores U1396C and U1339D, Al and Zr were determined after digestion using the same procedure as above, again alongside standard $\mathrm{BHVO} 2$ and blanks. Concentrations of these elements were determined using a Thermo X-Series ICP-MS at the University of 444 Southampton (Supplementary Table 1).

\section{$P$ depletion factors and $P$ release}

We used the GEOROC database to estimate the protolith composition of volcanic 
to non-outcrop samples, xenoliths and any mineral-specific analyses. This database was used

449 to estimate the composition of tephra prior to dissolution and diagenetic alteration. By normalising $\mathrm{P}$ to $\mathrm{Zr}$ and plotting this ratio against $\mathrm{Ti} / \mathrm{Zr}$ (elements which are largely immobile during diagenesis), the empirical relationship between the two ratios can be used to estimate

452 the original protolith composition following the method of ref. ${ }^{30}$, developed to estimate metal mobility in Cretaceous tephras (Supplementary Table 2). The linear regression representing this relationship is then used back-calculate the original composition of altered tephra (Supplementary Tables 2, 3, refs. ${ }^{58-64}$ ). These compositions, along with compositions of altered tephra, are then used to calculate depletion factors using the following equation (Equation 1):

$$
P_{D}=\frac{M_{P}^{L}}{M_{P}^{O}}=1-\frac{\left(\frac{C_{P}^{r e}}{C_{Z r}^{r e}}\right)}{\left(\frac{C_{P}^{O}}{C_{Z r}^{O}}\right)}(\text { Eq. 1) }
$$

The left side of the equation is the depletion factor, where $M_{P}^{O}$ original $\mathrm{P}$ mass in the protolith, $M_{P}^{L}$ is the loss of $\mathrm{P} . C_{P}^{r e}$ and $C_{Z r}^{r e}$ are the mass of $\mathrm{P}$ and $\mathrm{Zr}$ in tephra, and $C_{P}^{O} / C_{Z r}^{O}$ represents the ratio of $\mathrm{P}$ to $\mathrm{Zr}$ in the protolith, back-calculated from the linear regression of GEOROC data (Fig. 3, Extended Data Figures 1, 2).

\section{Estimating the extent and timing of volcanism during the Late Ordovician}

We use Monte Carlo simulations of variables associated with bentonite deposition during the Late Ordovician to estimate the size of the volcanic eruptions and associated ash deposition ${ }^{57}$. For the GICE period, we use values from published compilations of North American bentonites ${ }^{5,19}$ (Supplementary Table 4), and for the HICE we collate ages from published bentonites from China (Supplementary Table 5). For the period $455-450 \mathrm{Ma}$ (corresponding to period covering the GICE), we take the number of ash layers to be 100 based on observations ${ }^{19}$. We assume these ash layers represent eruptions of VEI 8 due to the 
location and characteristics of these bentonites, which constitute discrete centimetre-thick

471 horizons thousands of kilometres from any proposed source ${ }^{16,19}$. We assume each eruption 472 contained on average $1000 \mathrm{~km}^{3}$ erupted material ${ }^{18}$. To estimate how much erupted material 473 was ash, we use a value of $50 \%$, representing the likely proportions in Ultraplinian 474 eruptions $^{18,21}$. Since we are only interested, in the first instance, in the ash which may directly supply $\mathrm{P}$ to the ocean, we use an estimate of $50 \%$ ashfall in the ocean basins. This number is 476 based upon estimates of ashfall which has been subducted since the Ordovician, using 477 isopachs constructed from North American outcrops ${ }^{18}$, and paleogeographic reconstructions which indicate volcanism was linked to the opening of the Iapetus Ocean (Figure 2). For all variables used in equation 2, we apply standard deviations of all variables set at $25 \%$ of the variable mean, unless stated (Supplementary Table 6). 10,000 simulations of all variables were performed using the $\mathrm{r}$ package rtrucnnorm, and outputs were used to reconstruct likely 482 ash volumes (in $\mathrm{km}^{3}$ ).

For the period 450 - $440 \mathrm{Ma}$ (corresponding to period covering the HICE), a similar set of likely values for variables was constructed using published data on Chinese bentonite deposits $^{21}$. In this case, we use 88 ash layers as our mean, derived from the subtraction of 16 consider the uncertainty. In both cases, to estimate ash density, and the amount of $\mathrm{P}$ contained in the original 492 ashes, we use measured values from Icelandic ashfall ${ }^{32,33}$, with standard deviations derived 493 from the measurements. Using the ash volume estimates derived from these variables, and our 
depletion factors, we simulate 10,000 iterations for total $\mathrm{P}$ supply for each period (in mole P), using the following equation (Eq. 2):

$$
P \text { release }(\text { mole })=\left(\frac{V_{A s h} \times \rho_{A s h} \times P_{A s h} \times P_{D}}{30.97}\right) \times P_{o c e a n}(\text { Equation } 2)
$$

where $\mathrm{V}_{\text {Ash }}, \rho_{\text {Ash }}$ and $\mathrm{P}_{\text {Ash }}$ are the volume of ash (in $\mathrm{km}^{3}$ ), density of ash (in $\mathrm{kg} / \mathrm{m}^{3}$ ) and phosphorus content in ash (in wt \%). $\mathrm{P}_{\mathrm{D}}$ is the depletion factor of phosphorus, $\mathrm{P}_{\text {ocean }}$ is the proportion falling into the ocean and 30.97 is the molecular weight of $\mathrm{P}$, to convert from grams to moles. Such an exercise provides an absolute amount of $\mathrm{P}$ released for each period, but for modelling purposes, we must convert our total $\mathrm{P}$ supply values into flux (in mol $\mathrm{P}$ myr $1)$.

To do this, we develop a dataset of all reliably dated (i.e., excluding K-Ar or fission track dates) bentonites of Late Ordovician age from across the two primary volcanic provinces, China and North America/Baltica (Figure 2, refs. ${ }^{5,20,21,26-29,65-80}$ ). For each of the dates, we use a Monte Carlo based approach to generate 10,000 possible ages, constrained by published age and error values. We group the outputs of this exercise into $0.25 \mathrm{Myr}$ bins and produce probability density estimates for each bin (Fig. 1a, b). For each of the two volcanic provinces, we average across each bin to result in a probability density of each $0.25 \mathrm{Myr}$ period (Fig. 1c). This exercise results in two distinct peaks, representing the most likely period of volcanism for both provinces. For North America/Scandinavia, this peak is centred on 453.5 Ma. For China, the volcanic peak occurs 444.0 Ma. To represent these events in the model we then use a standard Gaussian curve with $\boldsymbol{\sigma}=0.4$, giving an event duration of around 2 Myrs. This width is informed by the duration of the carbon isotope excursions.

\section{Estimating P flux from weathering}

We estimate the spatial extent of erupted material during the Late Ordovician using an averaged value from a modelling study of Ordovician volcanism $\left(1.56 \times 10^{6} \mathrm{~km}^{2}\right.$; ref. $\left.^{60}\right)$. We 
518 then use $\mathrm{P}$ release value of $29.77 \mathrm{~kg} \mathrm{P} \mathrm{km}^{-2} \mathrm{yr}^{-1}$ as measured from basalts ${ }^{82}$. We estimate that

$51950 \%$ of the ash and lava was terrestrially emplaced based on the observations of ash

520 deposition considered previously ${ }^{18,21}$. By applying $20 \%$ errors to all of these values, we then

521 carried out 10,000 Monte Carlo simulations of each variable, before calculating the final flux

522 (in mol $\mathrm{P} \mathrm{myr}^{-1}$ ) by multiplying each iteration of each variable.

523 Biogeochemical modelling

$524 \quad$ We use the latest COPSE biogeochemical model ${ }^{39}$. We run the model baseline and add $525 P_{\text {force }}$ to the global bioavailable phosphorus weathering flux (Equation 3). This adds additional 526 phosphorus input during the Late Ordovician to the baseline model run.

$P_{\text {force }}=10^{-6} P_{\text {GICE }} \frac{\operatorname{norm}(t,-453.45,0.4)}{\operatorname{norm}(-453.45,-453.45,0.4)}+10^{-6} P_{\text {HICE }} \frac{\operatorname{norm}(t,-444,0.4)}{\operatorname{norm}(-444,-444,0.4)}($ Eq. 3$)$

Here $P_{\text {GICE }}$ and $P_{\text {HICE }}$ are the total $\mathrm{P}$ inputs from ash, weathering, and recycling in moles. Here norm is a normal function defined as norm(time,midpoint, $\boldsymbol{\sigma})$. $P_{\text {force }}$ is multiplied by 5 in some simulations to represent the additional recycling of $\mathrm{P}$ which is not captured in the COPSE model. This factor is determined by running a P-C cycling model which has an explicit representation of the shelf $\mathrm{f}^{43}$ and comparing the ratio between $\mathrm{P}$ input from weathering and overall marine $\mathrm{P}$ concentration versus the same metric in COPSE. The reader is referred to

534 Extended Data Figure 3 for the model comparison plots.

\section{Data Availability}

536 The authors declare that data supporting the findings of this study are available within the 537 article and Supplementary Information and Extended Data. All data have also been uploaded 538 to Figshare, at the following DOI addresses: http://dx.doi.org/10.6084/m9.figshare.14914893, 539 http://dx.doi.org/10.6084/m9.figshare.14914911,

540 http://dx.doi.org/10.6084/m9.figshare.14914896 and 541 http://dx.doi.org/10.6084/m9.figshare.14914890. 


\section{Code availability}

543 COPSE model code can be downloaded at https://github.com/bjwmills

544 Methods-only References

545 58. Bitschene, P. R., Mehl, K. W. \& Schmincke, H.-U. Composition and origin of marine ash

546 layers and epiclastic rocks from the Kerguelen Plateau, southern Indian Ocean (Legs 119 and 120).

547 Proc. Ocean Drill. Program, 120 Sci. Results 120, 135-149 (1992).

548 59. Schindlbeck, J. C. et al. One Million Years tephra record at IODP Sites U1436 and U1437:

549 Insights into explosive volcanism from the Japan and Izu arcs. Isl. Arc 27, e12244 (2018).

550 60. Rodehorst, U., Schmincke, H.-U. \& Sumita, M. Geochemistry and petrology of Pleistocene 551 ash layers erupted at Las Cañadas Edifice (Tenerife),. Scientific Results vol. 157 (1998).

552 61. Salisbury, M. J. et al. Deep-sea ash layers reveal evidence for large, late Pleistocene and 553 Holocene explosive activity from Sumatra, Indonesia. J. Volcanol. Geotherm. Res. 231-232, 61-71 554 (2012).

62. Derkachev, A. N. et al. Tephra layers of in the quaternary deposits of the Sea of Okhotsk:

556 Distribution, composition, age and volcanic sources. Quat. Int. 425, 248-272 (2016).

557 63. Schindlbeck, J. C. et al. Late Cenozoic tephrostratigraphy offshore the southern Central 558 American Volcanic Arc: 1. Tephra ages and provenance. Geochemistry, Geophys. Geosystems 17, $559 \quad 4641-4668(2016)$.

560 64. Allan, A. S. R., Baker, J. A., Carter, L. \& Wysoczanksi, R. J. Reconstructing the Quaternary 561 evolution of the world's most active silicic volcanic system: insights from an $\sim 1.65$ Ma deep ocean 562 tephra record sourced from Taupo Volcanic Zone, New Zealand. Quat. Sci. Rev. 27, 2341-2360 563 (2008).

564 65. Yang, S. et al. Duration, evolution, and implications of volcanic activity across the 565 Ordovician-Silurian transition in the Lower Yangtze region, South China. Earth Planet. Sci. Lett. 518, $566 \quad 13-25(2019)$. 
66. Tucker, R. D. U-Pb dating of Plinian-eruption ashfalls by the isotopic dilution method: a reliable and precise tool for time-scale calibration and biostratigraphic correlation. Geol. Soc. Amer. Abs. w/ Prog. 24, A192 (1992).

67. Oruche, N. E., Dix, G. R. \& Kamo, S. L. Lithostratigraphy of the upper Turinian - Lower Chatfieldian (upper Ordovician) foreland succession, and a U-Pb ID-TIMS date for the Millbrig volcanic ash bed in the Ottawa embayment. Can. J. Earth Sci. 55, 1079-1102 (2018).

68. Min, K., Renne, P. R. \& Huff, W. D. Ar/Ar dating of Ordovician K-bentonites in Laurentia and Baltoscandia. Earth Planet. Sci. Lett. 185, 121-134 (2001).

69. Samson, S. D., Patchett, P. J., Roddick, J. C. \& Parrish, R. R. Origin and tectonic setting of Ordovician bentonites in North America: isotopic and age constraints. Geol. Soc. Am. Bull. 101, 1175-1181 (1989).

70. Svensen, H. H., Hammer, Ø. \& Corfu, F. Astronomically forced cyclicity in the Upper Ordovician and U-Pb ages of interlayered tephra, Oslo Region, Norway. Palaeogeogr. Palaeoclimatol. Palaeoecol. 418, 150-159 (2015).

71. Bauert, H. et al. New U-Pb zircon ages of the Sandbian (Upper Ordovician) 'Big K-bentonite' in Baltoscandia (Estonia and Sweden) by LA-ICPMS. GFF 136, 30-33 (2014).

72. Compston, W. \& Williams, I. S. Ion probe ages for the British Ordovician and Silurian stratotypes. in Global perspectives on Ordovician geology (eds. Webby, B. D. \& Laurie, J. R.) 59-67 (1992). the Lower Silurian Longmaxi Formation on the Yangtze Platform, South China: Implications for stratigraphic correlation and environmental change. Chem. Geol. 509, 249-260 (2019). Earth Sci. 51, 493-498 (2008). 
593 the uppermost part of the Ordovician Wufeng Formation in the Haoping section,Taoyuan,Hunan.

594 Sediment. Tethyan Geol. 4, 597 (2012).

595 76. Yang, S. et al. Constraints on the accumulation of organic matter in Upper Ordovician-lower 596 Silurian black shales from the Lower Yangtze region, South China. Mar. Pet. Geol. 120, 104544 597 (2020).

598 77. Ge, X. et al. Mineralogical and geochemical characteristics of K-bentonites from the Late 599 Ordovician to the Early Silurian in South China and their geological significance. Geol. J. 54, 514-528 600 (2019).

601 78. Zheng, B. et al. Nature of the Late Ordovician-Early Silurian Xiaohe section, Hunan-Hubei 602 area, South China: implications for the Kwangsian Orogeny. Int. Geol. Rev. 62, 1262-1272 (2020).

603 79. Kunk, M. J., Sutter, J., Obradovich, J. D. \& Lanphere, M. A. Age of biostratigraphic horizons 604 within the Ordovician and Silurian systems. Geol. Soc. Mem. 10, 89-92 (1985).

605 80. Tucker, R. D., Krogh, T. E., Ross, R. J. \& Williams, S. H. Time-scale calibration by high606 precision $\mathrm{UPb}$ zircon dating of interstratified volcanic ashes in the Ordovician and Lower Silurian 607 stratotypes of Britain. Earth Planet. Sci. Lett. 100, 51-58 (1990).

608 81. Lefebvre, V., Servais, T., François, L. \& Averbuch, O. Did a Katian large igneous province 609 trigger the Late Ordovician glaciation?. A hypothesis tested with a carbon cycle model. Palaeogeogr. 610 Palaeoclimatol. Palaeoecol. 296, 310-319 (2010).

611 82. Hartmann, J., Moosdorf, N., Lauerwald, R., Hinderer, M. \& West, A. J. Global chemical 612 weathering and associated p-release - the role of lithology, temperature and soil properties. Chem. 613 Geol. 363, 145-163 (2014). 

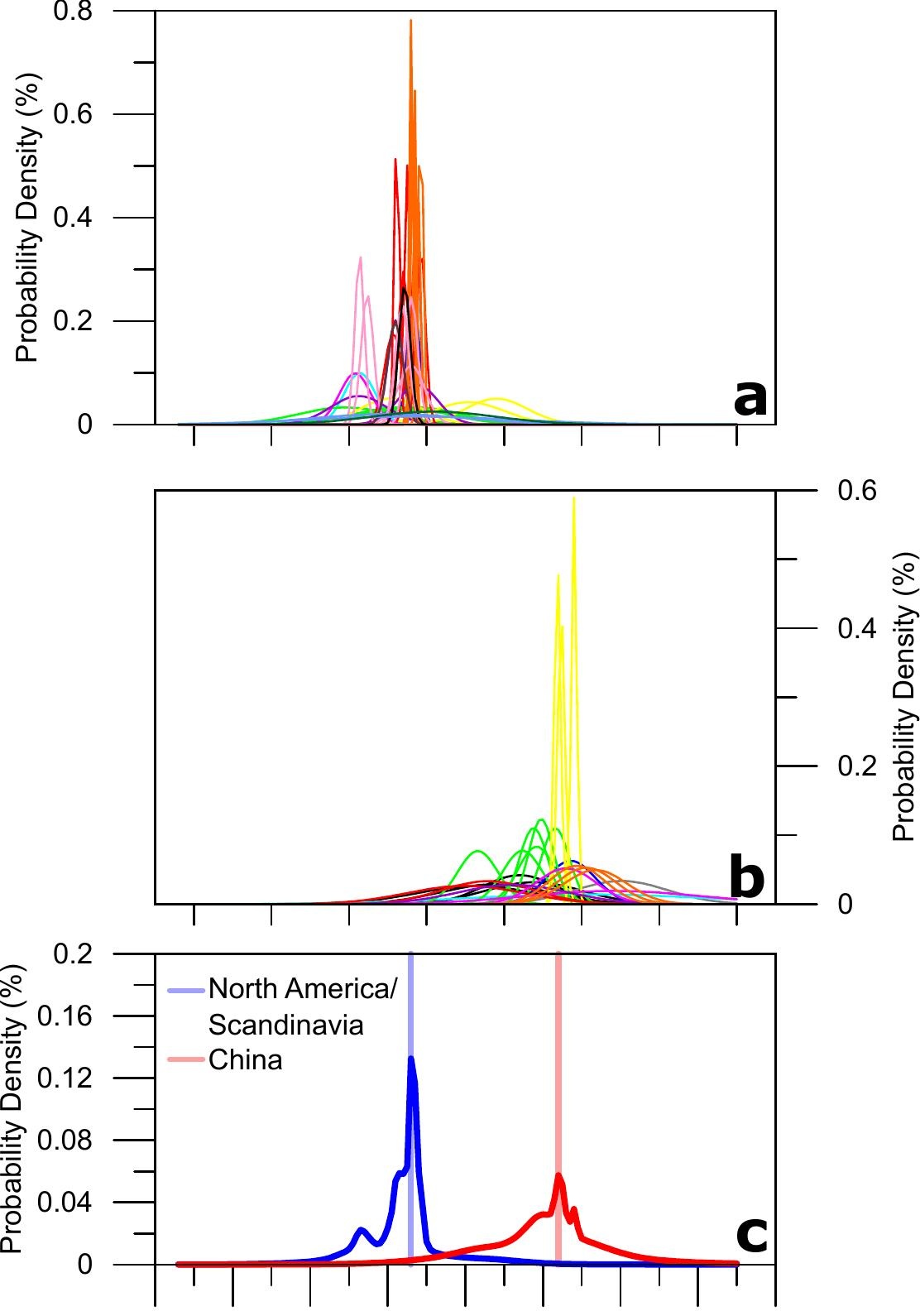

$\begin{array}{lllllllll}470 & 465 & 460 & 455 & 450 & 445 & 440 & 435 & 430\end{array}$ Age (Ma) 


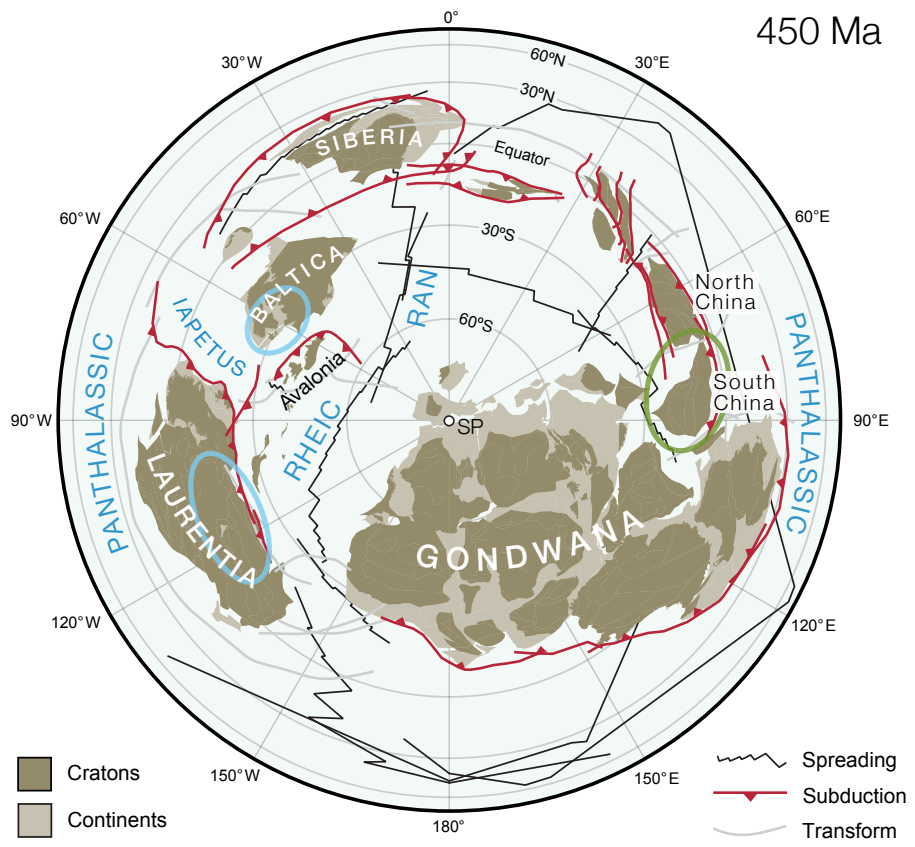



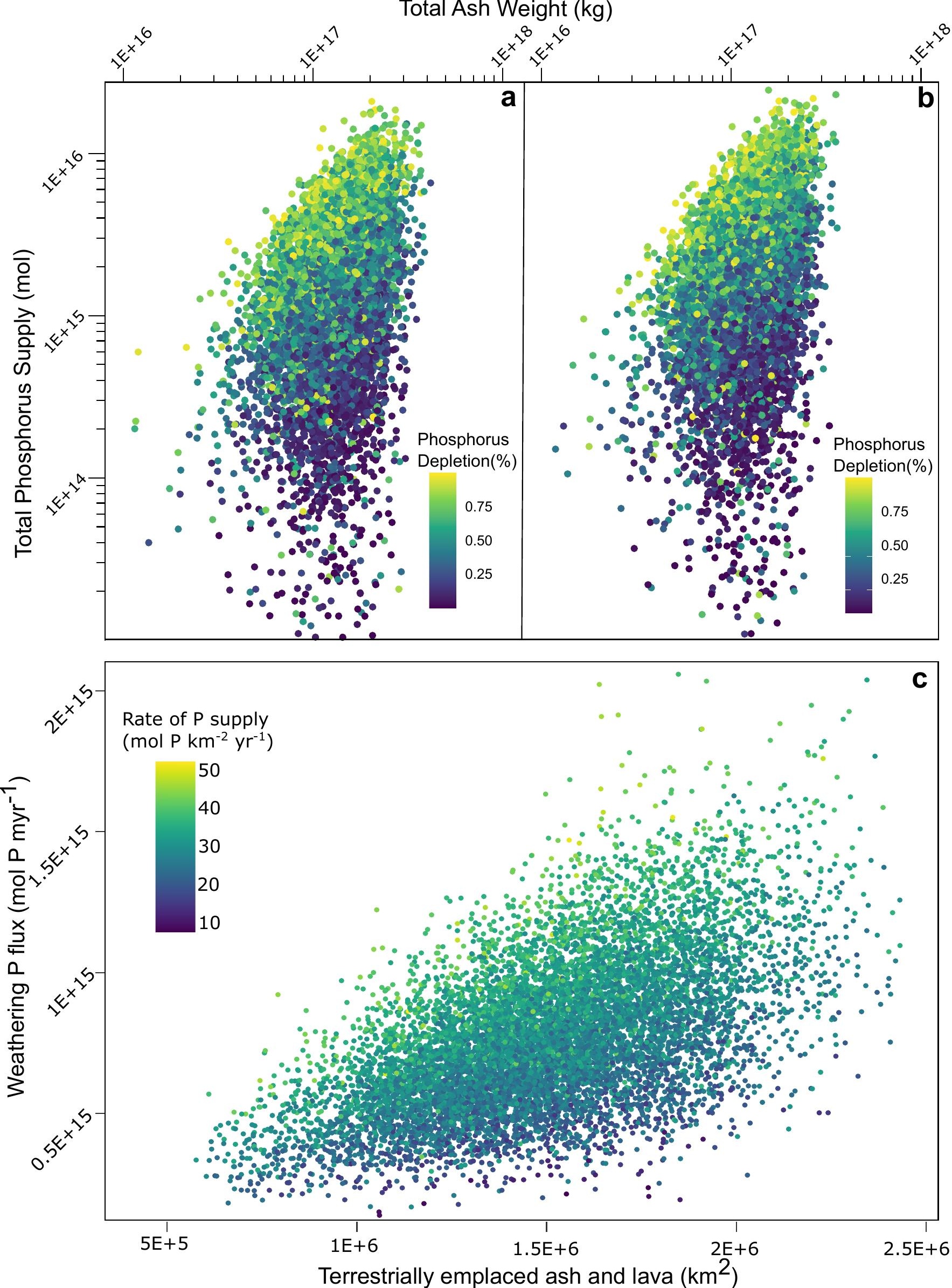
